\title{
The Phyllode Theory of the Monocotyledonous Leaf, with Special Reference to Anatomical Evidence.
}

BY

\author{
AGNES ARBER, D.Sc., F.L.S., \\ Fellow of Nerwham College, Cambridge.
}

With thirty-two Figures in the Text.

PAGE

I. The 'Phyllode Theory' from the Standpoint of External Morphology.

I. De Candolle's 'Phyllode Theory' . . . . . . . . . . . 466

2. The relation of the 'Phyllode Theory' to the theory of the origin of Monocotyledons through adaptation to the geophilous habit . . . . . . . . 468

3. The relation of the 'Phyllode Theory' to the theory of the aquatic origin of Monocotyledons . . . . . . . . . . . . . . 469

4. The 'Lamina' in certain Monocotyledonous leaves . . . . . . . . 470

5. An extension of the 'Phyllode Theory' to the leaves of certain Gymnosperms . . - $47^{2}$

II. The Bearing of Anatomical Evidence upon the 'Phyllode Theory'.

I. Introduction :

(i) The nature of the evidence . . . . . . . . . . . 473

(ii) The anatomy of Dicotyledonous petioles, phyllodes, and scale-leaves . . . . 473

(iii) Inverted bundles in Monocotyledonous leaves . . . . . . . . . . . 476

(iv) Midrib anatomy . . . . . . . . . . . . . . . 476

(v) Trécul's Theory . . . . . . . . . . . . . . . . . 477

2. The occurrence of phyllodic leaf anatomy among Mónocotyledons :

(i) Explanation of list of cases . . . • . . . . . . . 477

(ii) List of genera in which phyllodic leaf anatomy has been observed among Monocotyledons . . . . . . . . . . . . . . 478

3. Notes upon certain of the non-equitant and non-laminate cases enumerated . . . $4^{81}$

4. The isobilateral equitant leaf and its relation to other phyllodic types . . . . 482

5. Cases of 'phyllodic' anatomy which occur among Dicotyledons and the question of

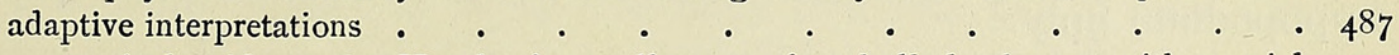

6. The anatomical evidence for Henslow's corollary to the phyllode theory, with special reference to the Pontederiaceae . . . . . . . . 488

7. Certain obscure anatomical features in Monocotyledonous leaves and their interpretation on the phyllode theory :

(i) Strands of fibres

(ii) Apical openings

8. The significance of the systematic distribution of phyllodic leaf anatomy among the Monocotyledons . . . . . . . . . . . . . 495

III. Summary.

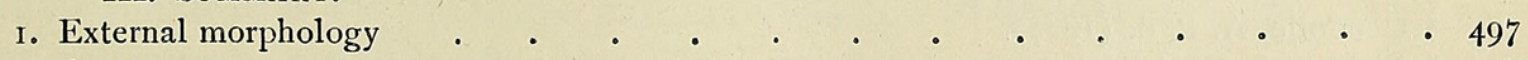

2. Anatomy . . . . . . . . . . . . . . . . . 497

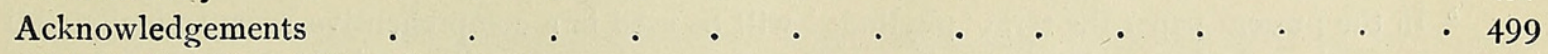

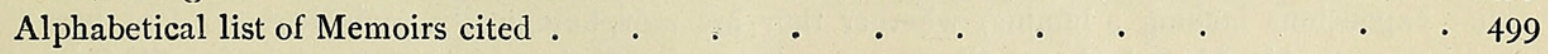

[Annals of Botany, Vol. XXXII. No. CXXVIII. October, 1918.] 


\section{The Phyllode Theory from the Standpoint of EXTERNAL MORPHOLOGY.}

\section{De Candolle's 'Phyllode Theory'.}

HERE is now a considerable balance of evidence in favour of the
view that the Monocotyledons are descended from Dicotyledonous ancestors. If this theory be accepted, it should become possible to trace homologies between the various organs occurring at the present day in the two groups, since both these groups are thus regarded as the modern representatives of an original common stock. From this point of view, the only structure in the mature plant which presents any difficulty is the leaf. The typical Monocotyledonous leaf is of a simple, more or less linear, form, with a sheathing base and parallel veins : how is such a leaf to be compared with that of a Dicotyledon, consisting, in its fullest expression, of leaf-base and stipules, petiole and net-veined lamina ? ${ }^{1}$ This question has naturally attracted the attention of morphologists, and an interpretation, which has become known as the 'phyllode theory', was put forward, with some reservations, by de Candolle ${ }^{2}$ not much less than a century ago. According to this view, the typical Monocotyledonous leaf does not correspond to the complete Dicotyledonous leaf, with its leaf-base and stipules, petiole and lamina, but is merely the equivalent of a petiole with a sheathing base. On this interpretation, the Monocotyledonous leaf, in spite of the reduction which it has suffered, still includes within itself, in many cases, parts derived from each of the two developmental regions of the leaf - the 'Oberblatt', which normally produces the lamina and petiole, and the 'Blattgrund' or 'Unterblatt', which gives rise to the leaf-base and stipules ${ }^{3}$ or, to use Bower's ${ }^{4}$ terminology, it is derived from the hypodium and mesopodium, the epipodium having been lost. It seems to the present writer probable, however, that in some cases reduction may have gone still farther, so that the leaf-base is alone represented, the leaf thus being derived from the hypopodium only. ${ }^{5}$

The phyllode theory is supported by the existence of a number of examples among Dicotyledons in which organs not dissimilar to typical

1 In the Phanerogams, with which in this paper we are alone concerned, the differentiation between lamina and petiole has become so firmly established that we are justified in treating these two regions as morphological entities. But the fact that this distinction of parts holds good for the higher plants in no way affects the possibility that the leaf, as a whole, may be the modern representative of a thallus-branch, borne by some ancestor of much greater antiquity than the earliest seed plant. See Lignier, O. (1908-9), \&c.

2 Candolle, A. P. de (I827).

3 Eichler, A. W. (186I).

4 Bower, F. O. (1884).

5 In the present paper the term 'phyllode' will be used in a comprehensive sense to include all foliar expansions lacking a lamina, whether they are morphologically equivalent to 'leaf base + petiole' or to 'leaf-base' alone; the two types may be distinguished as 'petiolar phyllode' and 'leaf-base phyllode'. 
Monocotyledonous leaves can be shown to be equivalent to leaf-bases, or to both leaf-bases and petioles. Such cases are numerous and familiar, and it is unnecessary here to do more than briefly to recall their existence. Those instances in which the reduced leaves correspond to leaf-bases, with or without stipules, are the commoner. A series of stages can, for example, be traced in such a bud as that of the Black Currant (Ribes nigrum, L.), showing transitions from a protective scale with parallel veins to a normal leaf with blade and petiole (Fig. 5 A (i)-(v), p. 474). Similar transitions can be readily followed in the earlier leaves of the long shoots of cultivated Roses and in the expanding bud of the Horse Chestnut. The scale-leaves of Monotropa, as de Candolle ${ }^{1}$ has pointed out, clearly correspond to the bases of the petioles in the related genus Pyrola, while the scale-like prophylls of Ranunculus Ficaria, L., are also equivalent to leaf-bases ( $p r$. in Fig. 4, p. 474).

The cases in which petiole as well as leaf-base undoubtedly plays a part in the leaf-like expansion are less numerous, but great theoretical interest attaches to them in connexion with the phyllode theory. Certain species of Oxalis, e. g. O. bupleurifolia, A. St. Hil. (Fig. 3 A, p. 474), show every stage in reduction of the lamina, correlated with a blade-like development of the petiole. The phyllode, in this case, is horizontally expanded, whereas in the numerous phyllodic Acacias it is most commonly flattened in the vertical plane; in one species, however (A. leptospermoides, Benth.), the phyllode is described as horizontal, ${ }^{2}$ and thus comparable with that of Oxalis bupleurifolia, while in others it is not flattened but almost radially symmetrical (e. g. Acacia scirpifolia, Meissn., Fig. I A and B, p. 474). That the phyllode in this genus is truly petiolar is deduced from the series which can be traced in certain seedlings between normal pinnate leaves with slender petioles-modified leaves with reduced laminae and flattened petiolesand, finally, phyllodic expansions with no trace of a lamina. Such a series is indicated in Fig. 2 A, p. 474), which represents Acacia neriifolia, A. Cunn., but a more complete set of transitional forms can often be found.

It is a commonplace of every text-book that one of the most distinctive features of Monocotyledons is the parallel venation of the leaves; the ' extraordinary uniformity' characterizing the main phenomena of venation in the striated type, to which the majority of Monocotyledons belong, was emphasized many years ago by de Bary. ${ }^{3}$ But no theory hitherto propounded regarding the origin of Monocotyledons has offered any satisfactory explanation of this well-marked character of the Class. To the present writer it appears that one of the chief merits of de Candolle's phyllode theory is that it explains the parallel venation of Monocotyledonous leaves in a perfectly unstrained way. For parallel veining is one of the most obvious characters of Dicotyledonous leaf-bases and petioles and of horizon-

$$
{ }^{1} \text { Candolle, A. P. de (1827). }{ }_{3} \text { Bary, A. de (1884) }{ }^{2} \text { Hochreutiner, G. (1896). }
$$


tally expanded phyllodes, so that, on de Candolle's theory, the venation of the Monocotyledonous leaf ceases to present any problem; it shows precisely those characters which might have been anticipated from the morphological nature of the organ. Even the more exceptional types of Monocotyledonous leaves fall into line from this point of view; for among the Iridaceae (p. 485) certain isobilateral, equitant leaves, which are not strictly parallel-veined, reproduce with great exactness the venation of various vertically expanded Acacia phyllodes.

\section{The relation of the 'Phyllode Theory' to the theory of the origin of Monocotyledons through adaptation to the geophilous habit.}

In a well-known series of papers, Miss Ethel Sargant ${ }^{1}$ set forth the views that Monocotyledons are descended from Dicotyledonous ancestors, and that the single cotyledon of the Monocotyledon is equivalent to the two cotyledons of the Dicotyledon, fused into an apparently single organ. The present writer, who is in entire agreement with these theories, wishes to suggest, as a minor corollary, that the single seed-leaf of the Monocotyledon may, like the foliage leaf, be interpreted as phyllodic; it will then be regarded as representing the fusion of the leaf-bases and petioles of the two ancestral seed-leaves, the laminae being absent. ${ }^{2}$ The phyllodic interpretation of the Monocotyledonous seed-leaf has the advantage of explaining the frequency, in this Class, of the slender cylindrical cotyledon, showing no differentiation into blade and petiole. A sheathing or winged base is sometimes prominently developed in Monocotyledonous seed-leaves, e.g. Tigridia, Colchicum, and Elettaria, ${ }^{3}$ while this region may even be isolated into an apparently distinct organ, as in the coleoptile of the Gramineae. ${ }^{3}$ This remarkable development of the cotyledon-base may perhaps be correlated with the loss of a true lamina.

To account for the origin of the cotyledonary fusion in Monocotyledons, Miss Sargant put forward the further theory that this fusion is due to adaptation to the geophilous habit. The present writer would prefer to formulate this view somewhat differently, and to regard tl e fusion of the two ancestral seed-leaves rather as a structural modification of unknown origin, whose occurrence facilitated the adoption of geophilous life, than as an actual adaptation to this type of habit. But, with this reservation, she agrees with the essential feature of Miss Sargant's view-namely, that the ancestral Monocotyledon was characteristically geophytic in habit--an idea with which the phyllode theory of the Monocotyledonous leaf is thoroughly in harmony. A study of the leaves of Dicotyledonous geophytes shows that

1 Sargant, E. (1903), (1904), (1908), \&c.

2 Where a blade occurs it may be regarded as a 'pseudo-lamina' comparable with those of the foliage leaves; see p. 470.

${ }^{3}$ Sargant, E., and Arber, A. (1915). 
their petioles play a part of considerable importance. The axis being subterranean, the entire work of raising the leaf lamina into the sunlight devolves upon the leaf-stalk, while its sheathing base often fulfils the additional function of protecting the younger leaves and the flower-buds in their passage through the soil. Salisbury ${ }^{1}$ has recently pointed out that, among the plants of our English woodlands, the most specialized type of vernal 'spear shoot', by which geophytes emerge into the upper air, is confined to certain Ranunculaceae and to Monocotyledons. He quotes Helleborus viridis, L., and Ramunculus Ficaria, L., as showing one or more sheathing scale-leaves (equivalent presumably to leaf-bases) enclosing and protecting the bud $;^{2}$ the cells at the apex of the scale are strengthened by thick cellwalls. These examples indicate the value which a reduced leaf may have in the economy of a geophyte. It is probable, in addition, that a system of firm, phyllodic, foliage leaves, with no delicate laminae to injurs, might form a bud which would be able to pierce the soil with special ease. There is obviously no necessary connexion between geophytism and a phyllodic type of leaf, since there are a vast number of well-established Dicotyledonous geophytes whose leaves have fully-developed laminae; at the same time, a phyllodic leaf might well be a considerable asset to a plant in adopting a geophytic mode of life.

\section{The relation of the 'Phyllode Theory' to the theory of the aquatic origin of Monocotyledons.}

The theory that Monocotyledons owe their peculiar characters to 'selfadaptation to an aquatic habit ' has been propounded by Professor Henslow. ${ }^{3}$ It is not possible here to enter into the arguments for and against this view : the present writer can only say that it appears to her less probable than the solution proposed by Miss Sargant. But at the same time it may be true that certain Monocotyledons adopted the water life at a very early periodin fact, not long after they diverged from the main stock of the Dicotyledons. ${ }^{4}$ The Alismataceae, whose flowers possess certain Ranalean features, are probably a case in point. The possible advantage of a narrow, linear leaf to submerged plants, especially to those growing in rapidlymoving water, has been frequently emphasized. It is thus clear that the phyllodic type of leaf is one that can accommodate itself to aquatic life with special ease. This may have been one of the factors concerned in establishing the numerous aquatic Families found among Monocotyledons.

It may well be that the phyllode theory, if accepted, will be claimed by those who adhere to Professor Henslow's view regarding the aquatic origin of Monocotyledons, as affording support to that hypothesis; for the

1 Salisbury, E. J. (I916).

${ }^{2}$ See Fig. 4, p. 474 of the present paper, for scale-leaves of Ranunculus Ficaria.

3 Henslow, G. (I893 and I9II).

${ }^{4}$ Sargant, E. (1908). 
reduction of a normal leaf to a phyllode seems, at first sight, to have taken place in three well-known aquatic Dicotyledons-Littorella, Subularia, and Lobelia Dortmanna, L. But it must be remembered that the phyllode nature of these leaves is not at present proven. To consider their morphological value would occupy space that cannot be spared in the present paper, but the writer hopes, later on, to deal with these leaves, as well as those of certain other Dicotyledons which are of interest from the standpoint of the phyllode theory.

\section{The 'Lamina' in certain Monocotyledonous leaves.}

So far we have only considered Monocotyledonous leaves in which no lamina is differentiated, but a large number of Monocotyledons existing at the present day possess a distinct lamina, e. g. Sagittaria, Smilax, various Dioscoreaceae, Araceae, Pontederiaceae, Scitamineae, Palms, \&c. How did this lamina arise, and what are its homologies? On the present writer's view of the phyllode theory, the leaf of the ancestral Monocotyledon consisted only of the leaf-base and petiole, and was entirely lacking in lamina. If the Monocotyledons are-as seems most probable-monophyletic, two explanations of the 'lamina' are open to us ; it must either be a revival of that organ as it occurs among the Dicotyledons, or an organ which has arisen de novo, as a modification of the apical part of the pre-existing phyllode, and thus not strictly homologous with the blade of a Dicotyledon. Professor Henslow, ${ }^{1}$ who-without formulating the problem quite in this way-appears to accept the second of these alternatives, has propounded the theory that the so-called lamina of those Monocotyledonous leaves which possess a distinct stalk and blade is merely an expansion of the apical region of the petiole, and thus that the 'aerial reticulated leaf-blades of Monocotyledons are not identical, but only imitative of the fibro-vascular system of an ordinary dicotyledonous leaf'. This interpretation certainly accords well with the venation of many Monocotyledonous leaves. The arrangement of the veins in Eichhornia speciosa, Kunth (Fig. 24, p. 489), for instance, looks decidedly as if the lamina had arisen through a spreading of the apex of the petiole. The transitional leaf forms produced in Sagittaria between the band and arrow-shaped types have also all the appearance of merely representing different degrees of expansion of the upper region of the petiole with correspondingly varying degrees of outward curvature and apical detachment of the veins. This series affords an illustration of the way in which the development of the 'pseudo-lamina'-as the present writer proposes to term the leaf-blade of the Monocotyledon-may conceivably have occurred in the course of phyletic history.

One merit of Henslow's theory is that it seems to contain the germ of an explanation of the curious fact that there is a certain general similarity

1 Henslow, G. (I9II). 
between the 'laminae' of Monocotyledons belonging to widely separated Families, and also a decided difference between such laminae and those of the Dicotyledons. It is not easy explicitly to define these resemblances and differences, but one or two of the more obvious points may be indicated. The prevalence of forms tending towards the sagittate or cordate-such as those which occur in the Alismataceae (Sagittaria), Pontederiaceae (Monochoria), Liliaceae (Smilax), Dioscoreaceae (Tamus), Araceae (Arum), and Orchidaceae (Nervilia)-becomes less inexplicable if we regard all these laminae as owing their skeletal form to the gradual separation of the originally parallel, petiolar veins. The similarity in the peculiar mode of dissection of the leaves of the Palmae, ${ }^{1}$ Cyclanthaceae, and certain Araceae is also a striking feature, since these Families are by no means closely related. Their leaves become more or less deeply incised or actually compound, by a process of necrosis or tearing along certain lines. This method is in no way homologous with the mode of origin of a compound leaf among the Dicotyledons; it suggests that the foliar member exhibiting it may be in an experimental stage of evolution, and that, if we may so express it, it lacks, the capacity for forming lobes or pinnae, which is part of the inherited equipment of a Dicotyledon. The tearing into strips, which is constantly suffered by the leaves of the Musaceae, is generally interpreted as an adaptation to a windy climate. But it may, perhaps, rather be regarded as another indication that the 'lamina' of a Monocotyledon is a somewhat imperfect organ, which only succeeds by cumbrous means in approximating to those complex forms which are reached in the Dicotyledons by direct and economical paths.

The greatest difficulty in the way of Henslow's extension of the phyllode theory seems to be that there is very great similarity between the leafblades of certain Ranunculaceae and of some of the Alismataceae, although these organs must be supposed, on this theory, to have had a different origin. De Candolle ${ }^{2}$ suggested that the leaves of such a plant as Ramunculus gramineus, L., might be interpreted as phyllodic, but this view is scarcely borne out by a comparative study of the Family. The nervation throughout the Ranunculaceae is on a uniform plan-the simple, Alismataceac-like leaves being connected by a series of intermediate forms with the more typical cases, which show no obvious resemblance to Monocotyledons. $^{3}$ The simpler leaves among the Ranunculaceae may thus be interpreted, not as the more primitive of the types found in the Family, but as reduced forms - an interpretation which minimizes the significance of their resemblance to the 'laminae' of the Alismataceae.

The phyllode theory has met with lively opposition at the hands of Goebel. ${ }^{4}$ He discusses the question chiefly in connexion with Sagittaria,

1 Trécul, A. (1853).

2 Candolle, A. P. de (I827).

3 Bitter, G. (I897).

4 Goebel, K. $\left(\mathrm{I}^{8} 9 \mathrm{I}-3\right)$. 
and takes the view that the band-like submerged leaves of this plant are not reduced leaves, in which the lamina has disappeared and the petiole alone survives, but rudimentary leaves, in which no differentiation of blade from petiole has occurred, and which are 'Hemmungsbildungen' (arrested stages) of the mature form of leaf. He supports this view by recalling that, in the ontogeny of the individual arrow-head leaf, stages are passed through corresponding, first, to the band-shaped submerged leaf and, secondly, to the oval floating leaf. It is true that these developmental facts are not easy to reconcile precisely with the phyllode theory as enunciated by de Candolle, but they fall readily into place when considered in the light of Henslow's extension of de Candolle's view. If the blade of Sagittaria be merely an expansion and development of the apical region of the petiole, the bandshaped leaf is indeed, as Goebel says, comparable with a complete air-leaf and not merely with its petiole. Where Henslow would part company with Goebel would be in regarding both the simple band-leaf and the highly differentiated air-leaf as homologous with the petiole alone of a typical Dicotyledon.

Henslow's corollary to de Candolle's theory is obviously even more difficult to prove or disprove than the main theory itself. As we shall see in a later section of this paper (p. 488), it gains a considerable degree of support from anatomical evidence.

\section{An extension of the 'Phyllode Theory' to the leaves of certain Gymnosperms.}

Though the Gymnosperms fall beyond the bounds of our present subject, it may be worth while to touch briefly upon the possibility of an application of the phyllode theory to their case. ${ }^{1}$ It seems to the present writer an indication of the validity of this theory, that it affords a point of view which reveals fresh interpretations of leaf morphology in other groups of Seed Plants.

Long ago Asa $\mathrm{Gray}^{2}$ suggested, as a possible alternative to other explanations, that the leaves of Pines, Cypresses, \&c., might be interpreted as homologous with petioles. He, apparently, did not pursue the matter, but his idea seems to the present writer a fertile one. There are many cases among the Gymnosperms to which such an explanation may well be applicable. The uniformity of leaf-structure in the Coniferae is very remarkable. Compton ${ }^{3}$ has recently drawn attention to the close relation to one another of the predominant types within the group, and to the association of the narrow acicular, linear-lanceolate, or cupressoid leaf-forms, with the absence of lateral pinnation of the foliar vascular system. He remarks that 'emphasis should be laid on the small power of the Conifers to vary the

1 The writer hopes to deal more fully with this subject in a later paper.

${ }^{2}$ Gray, A. (I887). $\quad{ }^{3}$ Compton, R. H. (I9II). 
character of their leaves'. The stereotyped external form and the lack of lateral veins receive a ready explanation if the leaves of the Coniferae are interpreted as phyllodes, equivalent in some cases to petiole and leaf-base, and in others, possibly, to the leaf-base alone. If this view be accepted, the leaves of Cordaites and the Coniferae will be regarded as bearing the same relation to those of the Pteridosperms and Cycadophyta as the leaves of Monocotyledons bear to those of Dicotyledons. It is impossible here to enter upon a detailed discussion of the subject, but it may be suggested that the Gnetales offer a special case which is of interest from this standpoint. The leaf of Gnetum may be compared with that of a Dicotyledon, while the scale-leaf of Ephedra and the parallei veined leaf of Welwitschia, with its continued basal growth, would be regarded as petiolar phyllodesor possibly as leaf-bases only-and thus morphologically comparable with the leaves of Monocotyledons.

The chief general result of the application of the phyllode theory to the Gymnosperms, is that the Coniferae come to be regarded as microphyllous by reduction, unlike the Lycopodiales, whose microphylly is probably a primary character of the group.

\section{The Bearing of Anatomical Evidence upon The Phyllode Theory.}

\section{Introduction.}

(i) The nature of the evidence.

The evidence hitherto brought forward for regarding the Monocotyledonous leaf as of a phyllode nature has, apparently, been based entirely upon external morphology. For some years the present writer unsuccessfully pondered the question whether it might not be possible to bring anatomical data to bear on the problem, but she was completely baffled until Solereder, ${ }^{1}$ in I913, $^{1}$, reported the discovery of vascular bundles of inverted orientation in the leaves of various Hydrocharitaceae. He compared the structure thus revealed to that of petioles, Acacia phyllodes, and various isobilateral equitant leaves, but he did not, apparently, attach any theoretical importance to it, or regard it as an indication of the true morphological nature of the leaves of this Family. His results, however, gave the clue the present writer was seeking, and in their light she returned afresh to the problem of how anatomical evidence could be used to test the phyllode theory of the Monocotyledonous leaf.

(ii) The anatomy of Dicotyledonous petioles, phyllodes, and scale-leaves.

As a preliminary to a general survey of the leaves of Monocotyledons it is necessary to refer very briefly to the anatomical characters of Dicotyle-

\footnotetext{
1 Solereder, H. (1913).
} 


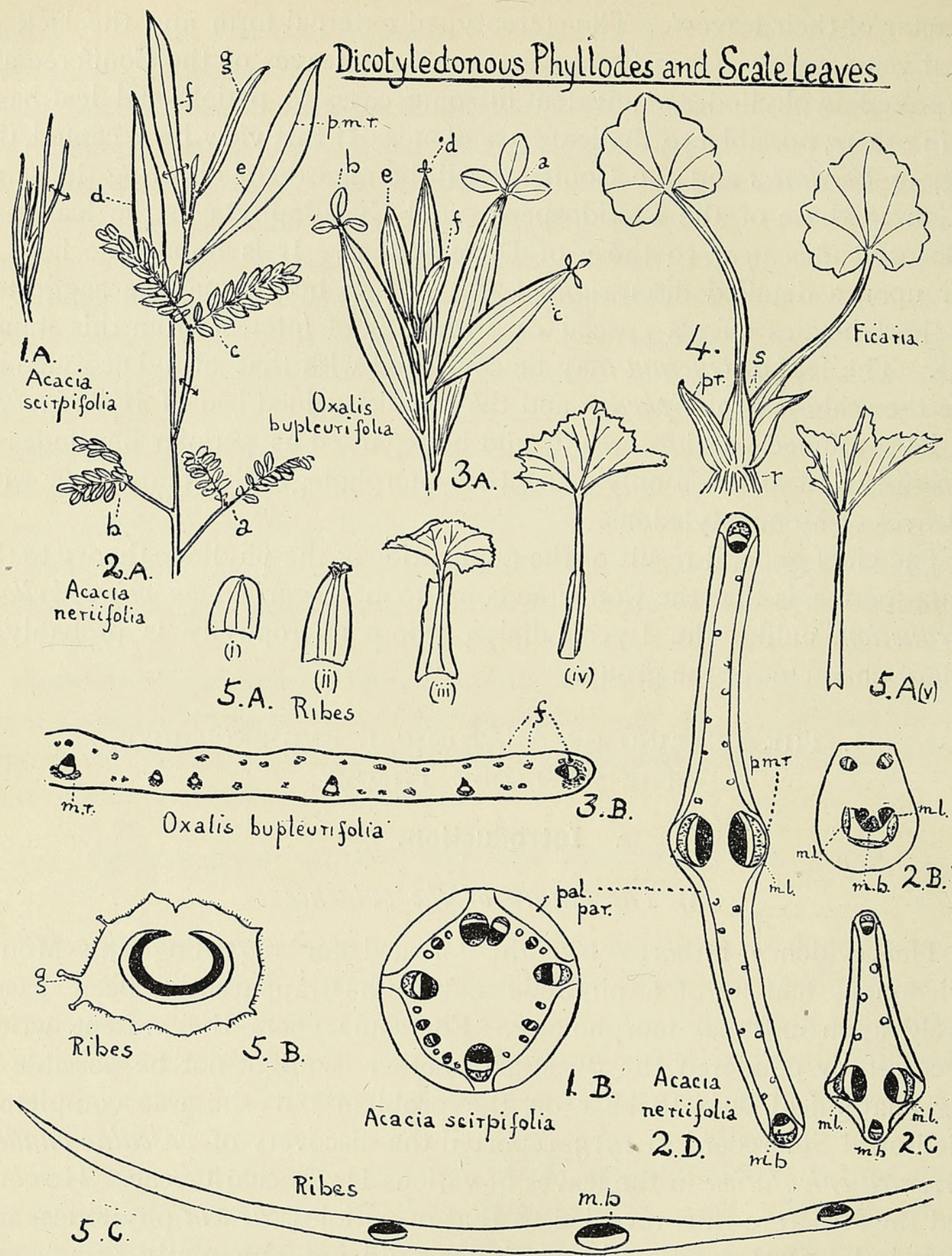

FIGS. I-5. (In all diagrams of sections, xylem is represented black, phloem white, and fibres, $f$, dotted.) Fig. I $\Lambda$ and B. Acacia scirpifolia, Meissn. Fig. I A. Apical region of shoot with cylindrical phyllodes (reduced). Fig. I B. Transverse section of phyllode $(\times 30)$; pal. par. = palisade parenchyma. Fig. 2 A, B, C, D. Acacia neriifolia, A. Cunn. Fig. 2 A. Upper part of seedling (reduced); $a$ and $b=$ normal leaves; $c=$ leaf with petiole slightly expanded; $d-g=$ phyllodes; p.m.r. = pseudo-midrib. Fig. 2 B. Transverse section of petiole of a leaf lower on the axis than leaf $a$. Fig. 2 c. Transverse section of petiole of leaf $c ; m . b .=$ median bundle; m.l. = main laterals. Fig. 2 D. Transverse section of phyllode $f ; p \cdot m . r_{0}=$ pseudo-midrib, derived from the two main laterals (m.l.); m.b. = median bundle. Figs. $2 \mathrm{~B}-2 \mathrm{D} \times 30$. Fig. $3 \mathrm{~A}$ and B. Oxalis bupleurifolia, A. St. Hil. Fig. 3 A. A pical region of shoot (reduced). The successive leaves, $a-d$, show progressive reduction of lamina, which in $e$ and $f$ is entirely lost. Fig. 3 B. Transverse section of part of phyllode including midrib, m.r. $(\times 30)$. Fig. 4. Ranunculus Ficaria, L. Part of basal region of plant to show two prophylls $(p r$.$) corresponding to sheathing bases (s)$ of normal leaves. Fig. 5 A, B, C. Ribes nigrum, L. Fig. 5 A (i)-(v). Successive leaves of bud, showing transitions from bud-scale to normal leaf (reduced). Fig. 5 B. Transverse section of petiole; $g=$ glandular emergence ( $\times$ I 7$)$. Fig. 5 c. Transverse section of bud-scale (incomplete); $m . b_{0}=$ median bundle $\left(\times I_{7}\right)$. 
donous petioles-both those of normal form and those known as 'phyllodes', which are expanded and lamina-like; we must also touch upon the anatomy of those scale-leaves which are equivalent to leaf-bases only.

The structure of petioles ${ }^{1}$ varies too much to lend itself readily to generalization. Disregarding a large number of minor complications, we may say, however, that most petioles, as seen in transverse section, are characterized by a more or less open arc or a complete circle of bundles; the result is that, although the majority of the bundles are usually orientated as in the lamina, certain of them, on the ventral or adaxial side, may come to be inversely orientated. The position, hence, is that inverted bundles are absent in typical Dicotyledonous laminae (excluding the principal ribs) and are sometimes present and sometimes absent in petioles; their presence is thus a distinctively petiolar character, but their absence is a character common to laminae and to some petioles.

The best-known examples of petiolar phyllodes are those found in a number of species of Acacia (Figs. I A and B and 2 A-D, p. 474, and Fig. 2I, p. 483) and Oxalis (Fig. $3 \mathrm{~A}$ and B, p. 474).

In the case of Acacia, the phyllodes, in the majority of species, are expanded in the vertical plane, but they may also be more or less radial in structure (Fig. I A and B, p. 474), while in one species they are described as horizontally expanded. ${ }^{2}$ The chief anatomical feature in which they diverge from true laminae is in the occurrence of two series of bundles of opposed orientation (Fig. 2 D, p. 474, and Fig. 2I, p. 483). Owing to the fact that in some species the earliest leaves of the seedlings have petioles that are scarcely flattened, we are able to trace the changes in the anatomy of the petiole as it becomes phyllodic (Fig. 2 B-D, p. 474).

The phyllodes of Oxalis bupleurifolia, A. St. Hil., which are expanded in the horizontal plane, do not show the two series of bundles characteristic of Acacia, but have one series of normal bundles, the marginal ones being horizontally placed (Fig. 3 B, p. 474). As an example of a bud-scale we may take that of Ribes nigrum, L. In this plant the normal petiole has an arc of xylem and phloem, almost meeting on the upper side to form a complete circle in transverse section (Fig. 5 B, p. 474). But in the bud-scales, which are obviously of leaf-base nature, the vascular supply is reduced to separate parallel bundles orientated as in an ordinary lamina (Fig. $5 \mathrm{C}$, p. 474).

The study of normal and phyllodic Dicotyledonous petioles and scaleleaves thus leads us to two conclusions: firstly, that the presence, in a Monocotyledonous leaf, of additional adaxial bundles with inverted orientation may well be interpreted as affording support to the phyllode theory; secondly, that the absence of such inverted bundles would in no way invalidate the theory. For their presence could scarcely be expected

2 Hochreutiner, G. (1 896 ). 
if the ancestral petiole, from which the phyllode was derived, happened to have an open arc of bundles; inverted strands are also lacking in the phyllodes of Oxalis bupleurifolia, whose petiolar nature is uncontested. Again, though some Monocotyledonous leaves are equivalent, on the phyllode theory, to leaf-bases plus petioles, it is probable that others are reduced to leaf-bases alone, and in these only normally orientated bundles would naturally be found (cf. bud-scales of Ribes nigrum). The leaves of certain species of Iris, for instance, are best interpreted as corresponding to the leaf-bases alone of other members of the genus. ${ }^{1}$

\section{(iii) Inverted bundles in Monocotyledonous leaves.}

To avoid obscurity, it may be well at this point to anticipate the succeeding sections of this paper so far as to state that the result of a general examination of the leaves of Monocotyledons is to reveal the frequent occurrence of phyllodic anatomy, especially in the more primitive Families. In order to leave no doubt as to what is here intended by the term 'phyllodic anatomy', it may be pointed out that all the cases represented in Figs. 6 to I4, p. 479, show the inverted bundles (i.b.) which the present writer regards as indicative of phyllodic structure. Figs. 9 and 10 are instances in which relatively little modification of the original petiolar anatomy has apparently occurred.

\section{(iv) Midrib anatomy.}

It may be objected, with some force, that the type of anatomical structure here called phyllodic might equally well be taken to indicate that the organ showing it is derived from the midrib region of a Dicotyledonous leaf, since many midribs (and some main laterals) closely resemble petioles internally.

On the other hand, there seems to be no positive evidence for the view that the typical Monocotyledonous leaf represents the midrib of an ancestral lamina. The simplicity of form in such a leaf; the uniformity of structure from the top of the leaf-base to the leaf-apex; the lack of any indication of external lateral appendages; the absence of any vestigial internal trace of pinnate or palmate venation ;-all these are points suggesting derivation from a leaf-base and petiole alone, rather than a more complex origin.

But since the midribs and main laterals of Dicotyledonous leaves may resemble petioles in structure and may show inverted bundles on the adaxial side, no Monocotyledonous genus is included in the list of phyllodic cases (pp. 478-8I) on the strength of its showing inverted bundles in the main ribs alone. It is only the occurrence of such bundles outside these ribs which 
can logically be used as evidence of phyllodic origin. For instance, Melocanna bambusoides, Trin., of the Gramineae, is not included, although it has inverted bundles in the midrib. ${ }^{1}$

(v) Trécul's Theory.

So far as has been ascertained, the only botanist who ever drew morphological conclusions from the existence of the type of leaf anatomy, here called 'phyllodic', was Trécul. ${ }^{2}$ In 1876 he published a paper dealing with the Amaryllidaceae, and incidentally with the Liliaceae, in which he compared the anatomy of the leaves of various species of Agave, Narcissus, Allium, and Aloe to that of inflorescence axes. He drew the conclusion that these leaves were really stem structures. It is obviously impossible to accept this view for many reasons. Even on anatomical grounds the resemblance of these leaves to petioles is far more precise than their resemblance to stems, since they are generally symmetrical only about a single median plane; this is shown, for instance, in the diagram of an Allium leaf, Fig. 9, p. 479. But Trécul's theory, though untenable, is of significance, since it shows that, forty years ago, one botanist had realized that the peculiar leaf anatomy of these Monocotyledons demanded a morphological explanation. The over-insistence on teleological interpretations, which was so rife especially in the latter part of the last century, has tended, in many cases, to obscure the morphological standpoint.

\section{The occurrence of phyllodic leaf anatomy among Monocotyledons.}

(i) Explanation of list of cases (pp. 478-8I).

We now have to make a general inquiry into the occurrence and distribution of inverted foliar bundles among the various Families of Monocotyledons. In the following table (pp. 478-8I) the genera in which phyllodic leaf structure is known to occur are enumerated. In the course of the present study, sections have been cut of selected representatives of most of the Families of Monocotyledons accessible to the writer; those cases of phyllode anatomy whose existence is reported here apparently for the first time are initialed (A.A.), while those in which the present writer has merely confirmed the published accounts are marked with an asterisk. Those in which the leaf is differentiated into petiole and 'lamina' and in which the 'lamina' shows phyllodic structure are marked (L); those marked (E) have isobilateral, equitant leaves with two series of bundles of opposed orientation; the remaining genera have leaves either flattened in the normal horizontal plane, or more or less thickened, or radially symmetrical, but not expanded in the vertical plane. It may be well to note in passing that the present writer regards both isobilateral, equitant leaves and these non-vertical leaves 
with inverted bundles as representing two comparable phases of phyllodic structure, between which transitions can be traced; to this point we shall return later. ${ }^{1}$

(ii) List of genera in which phyllodic leaf anatomy has been observed among Monocotyledons. ${ }^{2}$

\section{HELOBIAE.}

Potamogetonaceae. Cymodocea, sub-genus Phycoschoenus. ${ }^{3}$

Scheuchzeriaceae. Triglochin $4 *$ (Fig. Io, p. 479).

Scheuchzeria. ${ }^{5}$

Alismataceae. (L) Sagittaria (A.A.) (Fig. I I, p. 479, and Figs. 3I

Butomaceae. and $32, \mathrm{p} .492)$.

HydROCHARITACEAE. Enalus. ${ }^{7}$

Stratiotes. ${ }^{8}$

(L) Hydrocharis. ${ }^{8}$

(L) Limnobium. ${ }^{8}$

(L) Hydromystria. ${ }^{8}$

SPATHIFLORAE.

ARACEAE.

(E) Acorus * (Fig. I 8 A and B, p. 483).

FARINOSAE.

Pontederiaceae (L) Eichhornia (A.A.) (Fig. 24, p. 489, and Fig. 25, p. 490).

(L) Heteranthera (A.A.) (Figs. 29 and 30, p. 490).

(L) Pontederia (A.A.) (Fig. 23, p. 489, and Figs. 26 and 27, p. 490).

LILIIFLORAE.

JUNCACEAE.

LiLIACEAE.

Distichia. ${ }^{9}$

Oxychloe. ${ }^{9}$

Juncus $^{9 *}$ (certain species).

\section{Melianthoideae.}

Tofieldeae.

(E) Narthecium..$^{10 *}$

(E) Tofieldia $10 *$ (Fig. 20, A-C, p. 483).

(E) Pleea. ${ }^{10}$

(E) Nietneria. ${ }^{10}$

1 p. 482.

2 In this list the Families are arranged mainly according to A. Engler and E. Gilg's Syllabus der Pflanzenfamilien, 7 th edition, I 912.

${ }^{3}$ Sauvageau, C. (I89I). See note on p. $4^{81} .{ }^{4}$ Areschoug, F. W.C. (I878). See note on P. 482.

- Raunkiær, C. (1896).

7 Magnus, P. (1870).

${ }^{6}$ Sauvagean, C. (1893). See note on p. 482 .

9 Buchenau, F. (I906).

8 Solereder, H. (I9I3).

${ }^{10}$ Schulze, R. (I893). 

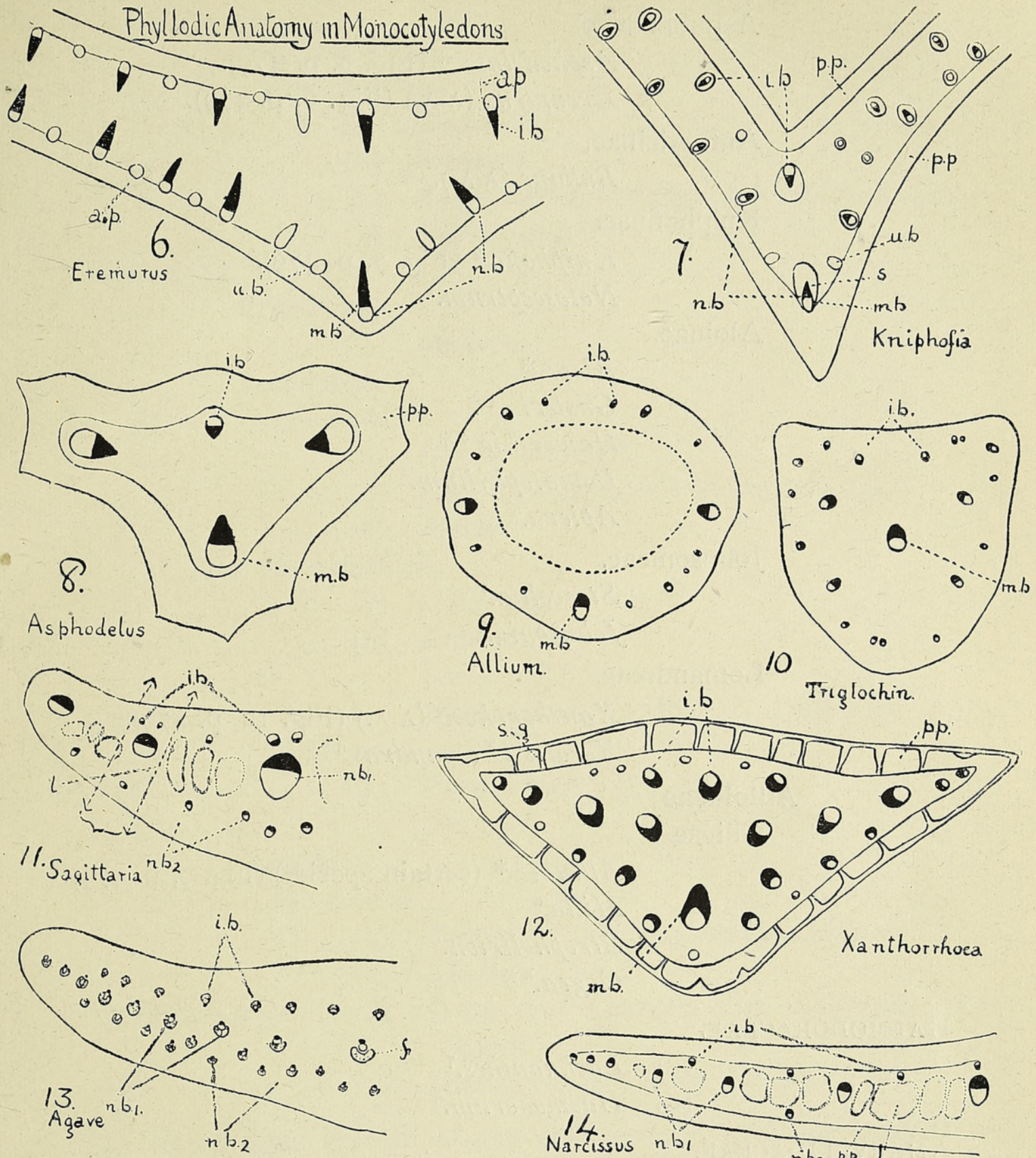

Tigglochin.

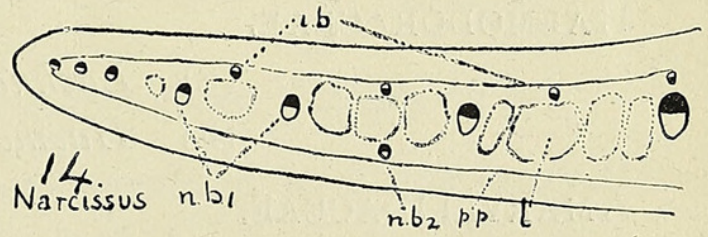

Figs, 6-I4. (Lettering throughout as follows: $-m . b_{.}=$median bundle; $n . b_{.}=$normal bundle ; $n . b_{.1}$. = normal bundle of main series; $n . b .2=$ normal bundle of second series ; $i . b_{0}=$ inverted bundle; $u . b .=$ undifferentiated bundle $; f_{0}=$ fibres $; l .=$ lacuna $; p \cdot p .=$ palisade parenchyma $; a \cdot p$. = assimilating parenchyma. Xylem throughout represented solid black, phloem white, and fibres dotted.) Fig. 6. Eremurus himalaicus, Baker. Transverse section of midrib and adjacent region of very young leaf ( $\times$ I 4). Fig. 7. Kniphofia caulescens, Baker. Transverse section of midrib region of leaf $(\times 14)$. Fig. 8. Asphodelus luteus, L. Transverse section of leaf $(\times 47)$. Fig. 9. Allium Cepa, L. Transverse section of upper part of leaf ( $\times$ I4). Fig. Io. Triglochin maritimum, L. Transverse section of leaf $(\times 23)$. Fig. I I. Sagittaria montevidensis, Cham. and Schlecht. Transverse section of part of leaf, including margin ( $\begin{array}{ll}x_{2} 3 \\ \text { ) }\end{array}$. The part enclosed between the arrows is shown in detail in Fig. 32, p. 492. Fig. 12. Xanthorrhoea sp. Transverse section of leaf ( $x$ I 4). Hypoderm and girders (s.g.) sclerised. Fig. I3. Agave densiflora, Hook. Transverse

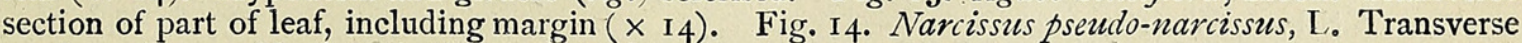
section of part of leaf, including margin ( $\left.\begin{array}{ll}x_{2} & 3\end{array}\right)$. 


\section{Asphodeloideae.}

Asphodelinae.

$$
\begin{aligned}
& \text { Asphodelus }{ }^{*} \text { (Fig. 8, p. 479). } \\
& \text { Eremurus (A.A.) (Fig. 6, p. 479). }
\end{aligned}
$$

Anthericinae.

$$
\text { Bulbine (A.A.). }
$$

Kniphofinae.

$$
\begin{aligned}
& \text { Kniphofia }{ }^{2} \text { (Fig. 7, p. 479). } \\
& \text { Notosceptrum. }^{1}
\end{aligned}
$$

Aloinae.

$$
\begin{aligned}
& \text { Aloe. }{ }^{3 *} \\
& \text { Gasteria. }{ }^{4} \\
& \text { Haworthia. }{ }^{4 *} \\
& \text { Lomatophyllum. } \\
& \text { Apicra. }^{5}
\end{aligned}
$$

Johnsonieae.

Stawellia. ${ }^{1}$

Johnsonia. ${ }^{1}$

Lomandreae.

Xanthorrhoea (A.A.) (Fig. I2, p. 479).

Xerotes (Lomandra). ${ }^{6}$

\section{Allioideae.}

Allieae.

Allium $^{3 *}$ (certain species) (Fig. 9, p. 479). Milla. ${ }^{6}$

- Stropholivion. ${ }^{6}$

Gagea. ${ }^{*}$ *

HAEMODORACEAE.
(E) Lachnanthes. ${ }^{7}$
(E) Haemodorum. ${ }^{6}$

AMARYLLIDACEAE.

\section{Amaryllidoideae}

\section{Amaryllideae.}

Narcisseae.

$$
\text { Amaryllis. }{ }^{8}
$$

$\operatorname{Narcissus}^{9} *$ (Fig. I4, p. 479).

1 Schulze, R. (1893).

3 Trécul, A. (I872).

5 Prollius, F. (I 884).

7 Scharf, W. (1892).

${ }^{8}$ Re, L. (1894). The observation relates to Amaryllis nivea, Schult.

${ }^{9}$ Trécul, A. (I 876$)$.
2 Berger, A. (1908).

4 Trécul, A. (I 872 ), and Prollius, F. (I884).

${ }^{6}$ Schmidt, C. (I89I). 
Agavoideae.

Hypoxidoideae.

Agave $^{1 *}$ (Fig. I3, p. 479).

Conostylideae.

(E) Conostylis. ${ }^{2}$

(E) Blancoa:2

(E) Anigozanthos $2 *$ (Fig. 19 A and B, p. 483).

IRIDACEAE. ${ }^{3}$

(E) Phlebocarya. ${ }^{2}$

\section{Crocoideae.}

\section{Romulea. ${ }^{4}$}

\section{Iridoideae.}

Iridineae.

(E) Hermodactylus. ${ }^{5}$

(E) Iris* (certain species) (Fig. I 7 A and B, p. 483).

(E) Moraea. ${ }^{*}$

Sisyrinchieae.

(E) Diplarrhena. ${ }^{5 *}$

(E) Libertia. ${ }^{*}$ *

Bobartia. ${ }^{4 *}$

Sisyrinchium $5 *$ (Fig. 16 A and B, p. 483).

Aristeae.

(E) Patersonia. ${ }^{4}$

(E) Aristea. ${ }^{7}$

\section{Ixioideae.}

Gladioleae.

(E) Tritonia $5 *$ (Fig. I 5 A-D, p. 483).

(E) Gladiolus. ${ }^{5 *}$

OrChidaceae. (E) Dendrobium anceps, Sw. (Aporum anceps, Lindl.) (A.A.).

(E) Maxillaria iridifolia, Reichb. (A.A.).

\section{Notes upon certain of the non-equitant and non-laminate cases enumerated.}

\section{PoTAMOGETONACEAE.}

Cymodocea isoetifolia, Aschers. Sauvageau ${ }^{8}$ describes the upper part of the cylindrical, rush-like leaf as showing a normally orientated median bundle and, in addition, a peripheral series of bundles with the xylem directed inwards.

1 Trécul, A. (18 76$)$.

2 Schmidt, C. (I89I).

3 The cases of phyllodic anatomy in this Family are so numerous that only certain typical genera are cited in this list.

4 Pax, F. (I888).

5 Chodat, R., and Balicka-Iwanowska, G. (1892). See also Balicka-Iwanowska, G. (1892-3).

6 Species examined, $M$. iridioides, L.

7 Scott, D. H., and Brebner, G. (I893).

8 Sauvageau, C. (189I). 


\section{SCHEUCHZERIACEAE.}

- Triglochin maritimum, L. In the solid, non-sheathing upper part of the leaf, the present writer has found, in agreement with Areschoug's ${ }^{1}$ observation, a median, normally orientated bundle, two main laterals obliquely placed, and a series of peripheral bundles with the xylem directed inwards ; the peripheral bundles towards the adaxial face are thus inversely orientated as compared with those of a normal lamina (Fig. 10, p. 479). T. G. Hill, who has also described the anatomy of the leaf, figures the vascular strands towards the adaxial surface as though their xylem were directed upwards. ${ }^{2} \quad$ This is apparently an error; the bundles are small and their inversion may easily be overlooked.

Scheuchzeria palustris, L. According to Raunkiær, ${ }^{3}$ the anatomy of the leaf of this plant is essentially similar to that of Triglochin maritimum.

Butomaceae.

Butomus umbellatus, L. Sauvageau ${ }^{4}$ describes the leaves as phyllodic; he says that the triangular transverse section shows an arc of normal bundles and a peripheral series of numerous small bundles. Sauvageau does not explicitly describe the orientation of these outer bundles, which seem to be somewhat reduced.

\section{JunCACEAE, Liliaceae, ANd Amaryllidaceae. ${ }^{5}$}

It is unnecessary to enter into details here concerning these Families, since it has long been known that they contain, besides numerous cases of leaves with a single row of normally orientated bundles, other cases of leaves thickened in various degrees, or even almost radially symmetrical, in which inverted bundles with the xylem directed downwards occur towards the adaxial face (Figs. 6-9, I2-I4, p. 479). Such a leaf as that of Allium Cepa, L. (Fig. 9, p. 479), may be closely compared with a cylindrical Dicotyledonous phyllode, such as that of Acacia scirpifolia, Meissn. (Fig. I B, p. 474). A third class of cases is even more striking from the point of view of the phyllode theory - that, namely, in which the leaf is not markedly thick, but in which there is, nevertheless, a series of inverted bundles towards the adaxial face, in addition to the normal series, e.g. Eremurus himalaicus, Baker (Fig. 6, p. 479), and Narcissus pseudo-narcissus, L. (Fig. 14, p. 479). The isobilateral equitant leaves belonging to these and other Families we shall consider in the next section of this paper.

\section{The isobilateral equitant leaf and its relation to other phyllodic types.}

The type of leaf occurring in many species of Iris and described as 'equitant' is, as is well known, characterized by a sheathing leaf-base,

1 Areschoug, F. W. C. (1878).

3 Raunkiær, C. (IS96).

2 Hill, T. G. (1900), P1. VI, Fig. 7 .

5 The present writer proposes to deal further with these Families in a later paper. 


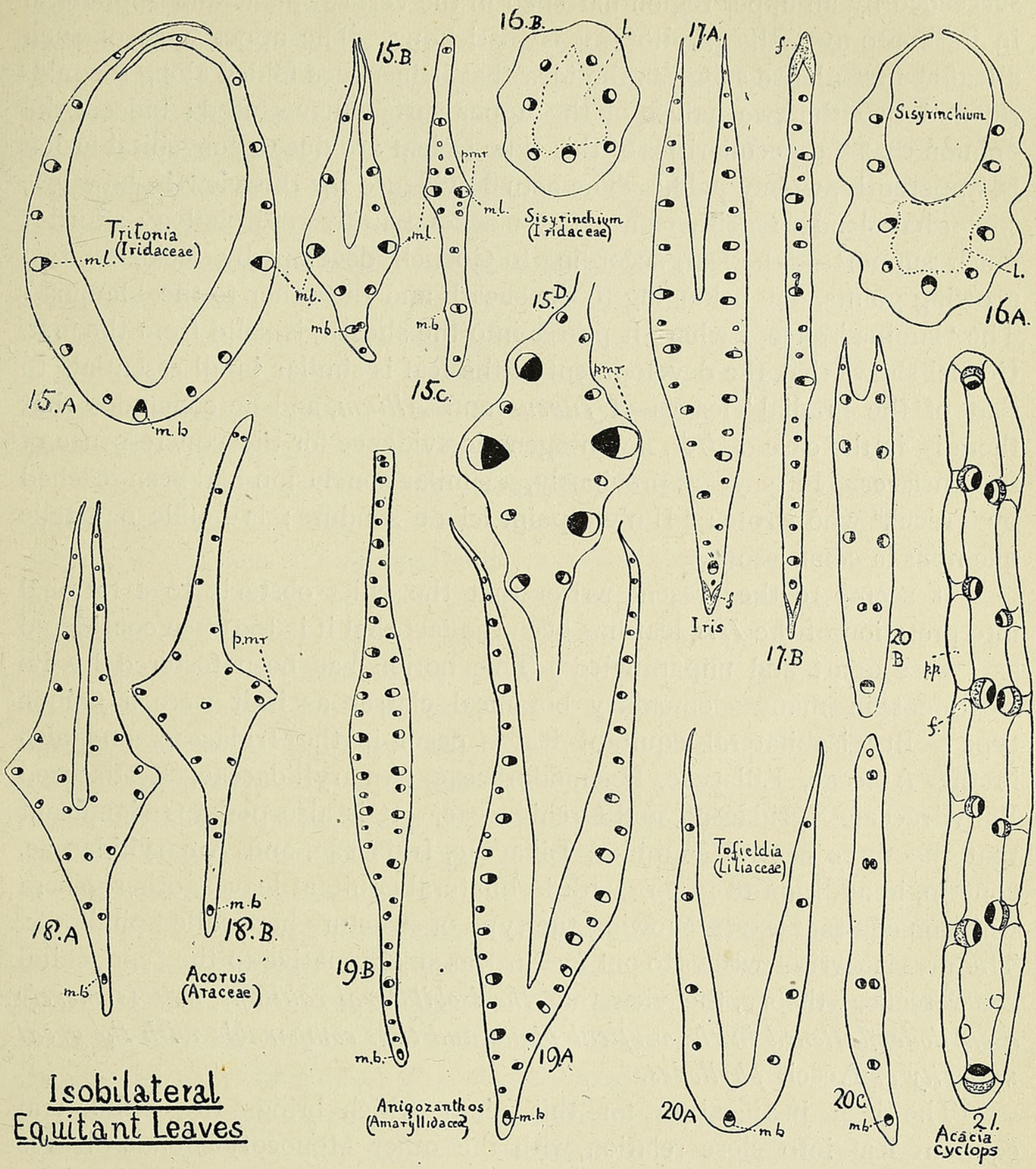

FIGs. I 5-2I. (Lettering throughout $:-m . b .=$ median bundle; $m . l$. = main lateral ; $l .=$ lacuna $; f .=$ fibres $; p . p_{.}=$palisade parenchyma. Xylem is represented solid black, phloem white, and fibres dotted. Fig. I5 A-D. Tritonia (garden hybrid). Fig. I5 A, B, C. Successive transverse sections of young leaf, passing through basal sheathing, and upper regions. Fig. I5 D. The pseudo-midrib $(p . m . r$.$) from an older leaf (x 23)$. Fig. I6 A and B. Transverse sections of sheathing and upper regions of leaf of Sisyrinchium sp. $(\times 23$ circa $)$. Fig. I 7 A and B. Iris sp. Trans-

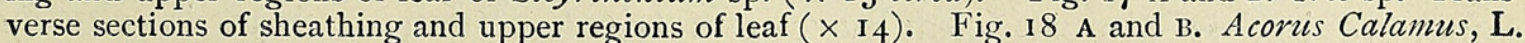
Transverse sections of sheathing and upper regions of leaf $(\times 7) \cdot p \cdot m \cdot r .=$ pseudo-midrib. A series of very small bundles lying close to both surfaces between the larger bundles has, for simplicity, been omitted. Fig. I9 A and B. Anigozanthos sp. Transverse sections of sheathing and upper regions of leaf $(x 7)$. Fig. 20 A-C. Tofieldia calyculata, Wahl. Series of transverse sections through basal sheathing and upper regions of leaf $\left(\begin{array}{ll}x & 23\end{array}\right)$. Fibrous bundle-sheaths not represented. Fig. 2 I. Transverse section of phyllode of Acacia cyclops, A. Cunn. $\left(\begin{array}{l}\times 23\end{array}\right)$. Some of the smaller bundles omitted. 
succeeded by an upper region flattened in the vertical plane and isobilateral in its anatomy; the phyllotaxy is distichous. The appearance of such a leaf at first glance suggests the idea that it has been folded along the midrib and that the two halves of the upper surface have fused; indeed, the opinion that the peculiarities of this type of leaf are due to congenital fusion is, apparently, widely held. ${ }^{1}$ The actual evidence for this view is, however, somewhat slender: neither ontogeny nor comparative morphology afford it much support. The leaf, according to Goebel, ${ }^{2}$ develops by means of two growing points, one belonging to the sheath and the other to the 'lamina'. The 'lamina', except where it passes into the sheath, is solid from the first. Goebel shows that the development of the leaf is similar in all essentials to that of the 'radial' leaves of Juncus and Allium, and he concludes that there is, in the case of Iris, no ontogenetic evidence for the concrescence of two surfaces. Fifty years previously, a similar conclusion had been reached by Trécul, ${ }^{3}$ who wrote: 'Il n'y a point ici de soudure; la feuille naît telle que nous la connaissons.'

It seems to the present writer that the chief obstacle to a rational interpretation of the Iris leaf has been the fact that it is too often considered as a case apart and unparalleled. This notion has been fostered by its treatment in many elementary botanical classes as if it were a unique type. But isobilateral equitant leaves occur in the Iridaceae, and also in the Araceae, Liliaceae, Haemodoraceae, Amaryllidaceae, Restiaceae, ${ }^{4}$ Philydraceae, Xyridaceae, and Orchidaceae. It is also perhaps significant that the three central Families, Liliaceae, Iridaceae, and Amaryllidaceae, contain, in addition to genera with isobilateral equitant leaves, other genera with non-equitant leaves, showing the type of structure here called phyllodic. The present writer wishes to put forward, as an alternative to the 'congenital concrescence' theory, the view that the isobilateral equitant leaf is merely a phyllode flattened in the vertical plane, and thus comparable with the great majority of Acacia phyllodes.

The best justification for this view-which brings the isobilateral equitant leaf into close relation with the other Monocotyledonous leaves exhibiting phyllodic anatomy-is to be found in a comparative study of the Iridaceae.

Among the Iridaceae there are, besides the vertical equitant leaves, others, such as that of Sisyrinchium (Fig. I6 A and B, p. 483), in which the upper region is almost radially symmetrical. Such a leaf is closely comparable with the phyllodic leaf of Allium Cepa (Fig. 9, p. 479), and with the phyllodes of Acacia scirpifolia (Fig. I B, p. 474) and of Rhyticarpus difformis. ${ }^{5}$ We need only imagine the leaf of Sisyrinchium flattened and

\footnotetext{
1 Chodat, R., and Balicka-Iwanowska, G. (I892); Massart, G. (I894).

2 Goebel, K. (1905).

4 Anarthria, according to Brown, R. (I810). 
expanded in the vertical plane to produce an isobilateral leaf similar to the equitant leaf of Tofieldia (Liliaceae, Fig. 20 A-C, p. 483) or Iris (Fig. I7 A and B, p. 483). This comparison is facilitated by the fact that some Iris leaves, e. g. those of $I$. temifolia, ${ }^{1}$ have an oval transverse section, forming, as it were, a transition towards the Sisyrinchium type. That vertical flattening is in itself of no morphological significance, is demonstrated by the comparison of the cylindrical and flattened petioles occurring in different species, or even in different ontogenetic phases of the same species, within the genus Acacia.

Certain species within the genus Iris, such as $I$. persica, ${ }^{2}$ L., and I. orchioides, Carr., have leaves expanded in the horizontal plane with no flattened vertical region. These leaves are possibly equivalent to the leafbases alone in the case of the other Irises. ${ }^{3}$

The phyllode theory seems completely to explain the anatomy of the isobilateral equitant leaf; in this respect a comparison with the bundle system of various Acacia phyllodes proves illuminating. The comparison of an Iris leaf, with its two opposed series of bundles, to an Acacia phyllode has, indeed, been frequently made, ${ }^{4}$ but no one seems to have hitherto taken the view that the similarity which they show yields the clue to the interpretation of the isobilateral equitant leaf. The flattening of a petiole in the vertical plane can scarcely take place without the production of two opposed series of bundles; Fig. 2 B-D, p. 474, shows the actual anatomical effect of flattening and expansion in successive petioles of the seedling of Acacia neriifolia. The phyllode of this Acacia is closely comparable in venation and anatomy with the leaf of Tritonia ${ }^{5}$ (Iridaceae, Fig. I5 A-D, p. 483). In both Acacia neriifolia and Tritonia there is a specialized region, which the writer proposes to call a 'pseudo-midrib' (p.m.r.), in which the two main laterals (m.l.) are concerned. Such a pseudo-midrib is a common character of the Tribe Gladioleae ${ }^{6}$ to which Tritonia and Gladiolus belong, while it occurs also in a slightly modified form in some species of Iris of the Section Tetragonae. ${ }^{7} \quad$ Outside the Araceae it is found in Acorus (Araceae, Fig. I $8 \mathrm{~A}$ and B, p. 483 ). In many other isobilateral equitant leaves no such distinct pseudo-midrib is evident, e. g. Tofieldia (Liliaceae, Fig. 20 A-C, p. 483), Anigozanthos (Amaryllidaceae, Fig. I9 A and B, p. 483), and species of Iris not included in the Section Tetragonae, such as that

1 Chodat, R., and Balicka-Iwanowska, G. ( $\left.189^{2}\right)$.

${ }^{2}$ Balicka-Iwanowska, G. (I892-3).

3 The present writer hopes to deal more fully with the morphology and anatomy of the leaves of the Iridaceae in a later paper, so all discussion of such forms as Crocus, Romulea, Cipura, \&c., is omitted here.

1 e. g. Bower, F. O. (I 888)

5 The species examined and figured here was a garden hybrid, probably between Tritoria crocata, Ker-Gawl., and Montbretia pottsii, Baker.

${ }^{6}$ Chodat, R., and Balicka-Iwanowska, G. (1892).

7 Balicka-Iwanowska, G. (1892-3). 
represented in Fig. I7 A and B, p. $48_{3}$; these cases are best compared with such Acacias as $A$. cyclops (Fig. 21, p. 483).

Figs. I5-20, p. 483 , illustrate the essential similarity between isobilateral, equitant leaves belonging to different Families. The main anatomical difference between them depends on whether the bundles in the flattened region are opposite one another or alternating. In the former case they sometimes fuse to double bundles with a single xylem and two phloem groups (Tritonia, Fig. I5 C, and Tofieldia, Fig. $20 \mathrm{C}$ ). If they alternate, the thinner part of the flattened leaf may contain a single series of bundles, some with their xylem directed towards one face and some towards the other (Anigozanthos, Fig. I9 B, and Iris sp., Fig. I7 B). In the case of Tritonia, a slight complication is introduced by the production of a double bundle through the branching of the median strand ${ }^{1}$ (Fig. I $5 \mathrm{~A}-\mathrm{C}$ ), and the development of a wing to the midrib. But these variations are unimportant from our standpoint, and do not detract from the essential uniformity of the anatomical type.

A problem which seems to demand a solution is why, in Monocotyledons, we only meet with leaves flattened in the vertical plane in cases where the phyllotaxis is distichous. The answer probably is that, in the case of a leaf with the broad sheathing base characteristic of a Monocotyledon, vertical flattening is almost a physical impossibility if the leaves are arranged in more than two ranks. For if the main part of the leaf is flattened vertically, the sheath, at least in its upper region, must necessarily be correspondingly flattened, and hence the base of the next leaf can only be fitted in, if it be placed exactly opposite to the first. In other words, we may say that, amongst Monocotyledons, the development of a vertically flattened phyllode is conditioned by a distichous leaf arrangement, while in Acacia the narrow attachment to the axis renders the leaf independent of any special type of phyllotaxis. The opportunity for the development of a vertical phyllode must have frequently occurred among Monocotyledons, for distichous phyllotaxy is noticeably widespread in this Class. In addition to those Families already enumerated, in which-if we may so express it - advantage has been taken of the distichous habit to develop a vertical phyllode, there are numerous other cases of two-ranked leaves. Distichy is common amongst the Amaryllidaceae, Scitamineae, Gramineae, Potamogetonaceae, Typhaceae, and Sparganiaceae, while cases occur in the Liliaceae, Juncaceae, Hydrocharitaceae, Pontederiaceae, and Centrolepidaceae. We may conclude that the association of the vertical leaf with distichy does not in any way invalidate the phyllode interpretation; it may, however, seem to the supporters of the 'concrescence theory' in some respects favourable to their view.

A case which might perhaps serve to support the 'concrescence

1 Chodat, R., and Balicka-Iwanowska, G. (I892). 
theory' (though the present writer is not aware that it has ever been so used) is that of Phormium tenax, Forst. The leaf of this plant is vertically flattened for a short distance, but opens out above into an expanded portion. It is possible, however, that we have here an instance of an isobilateral leaf which has developed a 'pseudo-lamina' at its apex. It is perhaps significant that, though most of the other Hemerocallineae have no lamina, one genus, Hosta (Funkia), is characterized by possessing a blade whose venation distinctly suggests that it may have been developed by an expansion of the upper part of the petiole (Fig. 22).

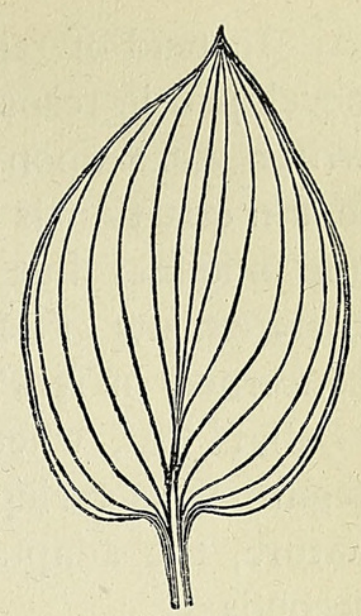

FIG. 22. Funkia grandiflora, Sieb. and Zucc. Upper part of petiole and 'lamina' to show venation (reduced).

\section{Cases of 'phyllodic' anatomy which occur among Dicotyledons and the question of adaptive interpretations.}

The anatomical argument in the present paper is based upon the assumption that the occurrence of inverted bundles, which characterizes the leaves of a large number of Monocotyledons, is a feature which is normally absent from the laminae of Dicotyledons (excluding the principal ribs). If it were a common characteristic of both Dicotyledons and Monocotyledons, the contentions here advanced would fall to the ground. It is, of course, well known that the vast majority of Dicotyledonous laminae exhibit, in transverse section, only a single series of bundles. But it might possibly be argued that extra, inverted bundles are not an ancestral feature, as here maintained, but represent a structural adaptation, and might thus be expected to occur in Dicotyledons as well as Monocotyledons if the thick or succulent nature of the leaf rendered such a development advantageous. It is not possible here to treat this question at length, but it may be pointed out that many succulent leaves among the Dicotyledons, and some among Monocotyledons, are furnished with normally orientated bundles only, so that there is obviously no inevitable connexion between succulence and inverted bundles. Certain Dicotyledonous leaves, on the other hand, in which the anatomy is more or less radial and a peripheral series of bundles occurs, may possibly be interpreted either as laminae reduced to the midrib alone, or as true petiolar phyllodes. ${ }^{1}$ There is no difficulty in supposing that phyllodic leaf-structure may have arisen more than once in the phyletic history of the Angiosperms - though never with such far-reaching consequences as when it appeared in the ancestral Monocotyledon.

1 The writer hopes to consider certain of these cases in a later paper, as well as the various types of reduced leaf found in the perianth of the Angiosperms. 
Instead of regarding a peripheral series of bundles as an adaptation developed in response to the succulent and xerophilous habit, the present writer looks upon the existence of such bundles as an indication that the leaf in question is morphologically equivalent to a petiole, or to a petiole and midrib; but, since peripheral bundles happen to be adapted to the requirements of a succulent leaf, they may well have been one of the factors concerned in rendering a xerophilous habit possible. On this view, the 'radial' leaf, whether it belongs to a Dicotyledon or Monocotyledon, is regarded as owing its form and structure primarily to its morphological nature, the adaptational use of its structural peculiarities being entirely secondary.

It may be added that it seems scarcely possible to suppose that the inverted series of bundles in the relatively thin leaf of the Daffodil (Fig. I4, p. 479), for instance, can be of 'survival value or can represent a special adaptation to the mode of life, while such bundles are absent in the leaf of the Bluebell. The general structure and mode of life of the two plants is closely similar, and the Daffodiloes not show any obvious superiority in the struggle for existence. But this point must not be laboured, since it involves the whole vexed question of the meaning of adaptation.

\section{The anatomical evidence for Henslow's corollary to the phyllode theory, with special reference to the Pontederiaceae.}

Professor Henslow's corollary to de Candolle's phyllode theory has already been outlined (p. 470). He bases his view entirely on external morphology and the macroscopic characters of the venation, but the present writer wishes to draw attention to some cases in which his theory appears to receive definite support from the anatomical structure of the leaves in question.

The Pontederiaceae will be considered in some detail in this connexion, since the peculiarities of their leaf anatomy seem hitherto to have escaped the attention of botanists. The leaves of this Family generally have a sheathing leaf-base, a petiole which is sometimes much swollen, and a 'lamina'. In external appearance and venation the leaves of Pontederia (Fig. 23, p. 489) and Eichhornia (Fig. 24, p. 489) distinctly suggest that the 'laminae' are produced by expansion of the apical regions of the petioles, and that they are thus 'pseudo-laminae' and not equivalent to the blades of Dicotyledonous leaves. The anatomy confirms this idea in a striking fashion. Fig. 28, p. 490 , shows the transverse section of a petiole of Pontederia cordata, L., with inverted bundles towards the upper side. When the 'lamina' is cut transversely, its structure is found to be exactly such as might have been anticipated on the theory that it is produced by extreme flattening and expansion of the petiole in the horizontal plane (Fig. 26, 
p. 490). For, instead of the bundles all being orientated with the xylem upwards, as is usual in laminae, the vascular strands, though in a single series, are orientated, some normally $(n . b$.$) (including the median bundle$ $m . b$.$) , the majority inversely (i.b.), and a few obliquely (o.b.). A small$ part of the transverse section is shown in greater detail in Fig. 27, p. 490. In this drawing the central and largest bundle is seen to be normally orientated, but the bundles on either side of it have the xylem below and phloem above.

In the heart-shaped 'lamina' of Heteranthera reniformis, Ruiz and
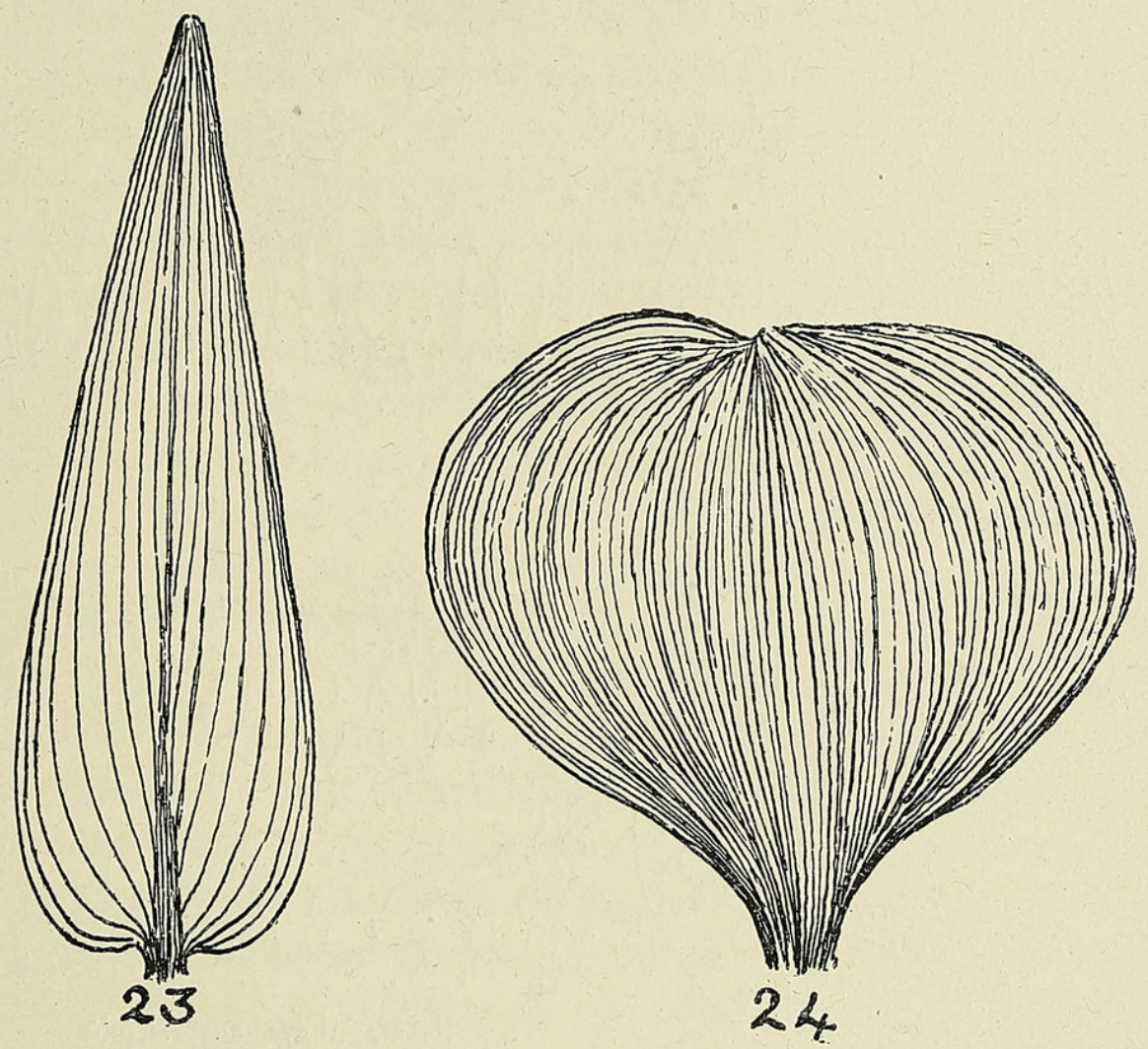

FIGS. 23 and 24. Fig. 23. 'Lamina' of Pontederia cordata, L. (natural size), to show venation.

Fig. 24. A small 'lamina' of Eichhornia speciosa, Kunth (natural size), to show venation.

Pav., a very similar bundle arrangement is found (Fig. 29, p. 490). Here only the midrib and main laterals are normally placed, the remaining bundles being inverted.

The orientation of the bundles in these and other members of the Pontederiaceae closely recalls the arrangement in the leaf of Iris shown in Fig. I 7 B, p. 483 , and also that in the thinner marginal regions of the isobilateral leaf of Anigozanthos (Fig. I9 B, p. 483), but the flattening in these cases takes place in the vertical and not in the horizontal plane.

The 'lamina' of Eichhornia speciosa, Kunth (Fig. 24), differs from that of those other members of the Family here considered, in its much greater thickness. Inverted bundles occur, not only in the thick basal region-in 

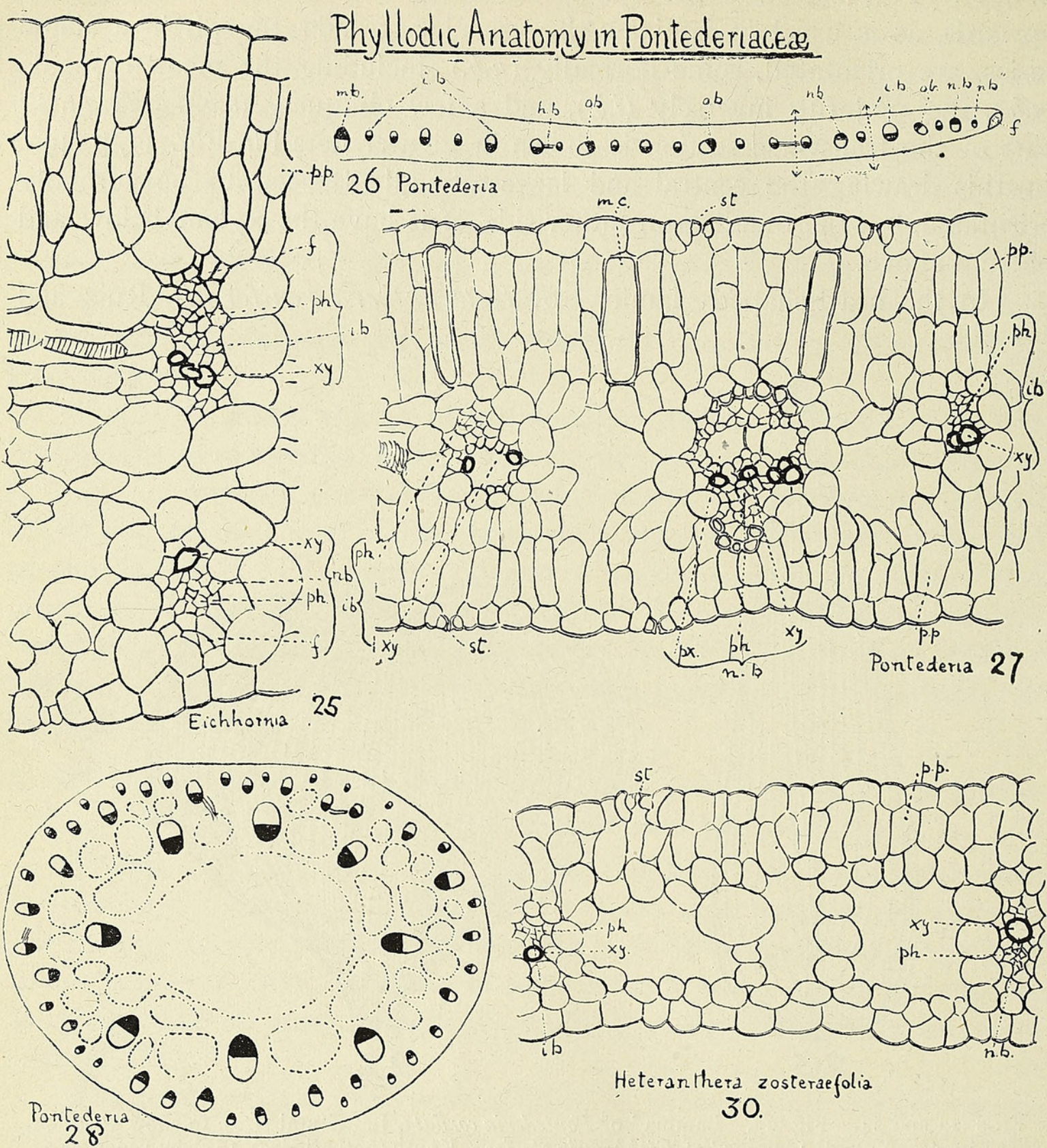

Heterantherd zosteraefolia

30.

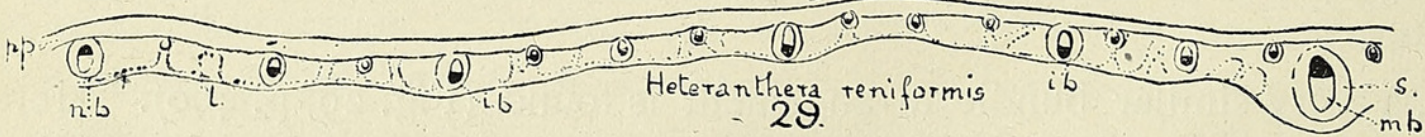

F!Gs. 25-30. Pontederiaceae. Fig. 25. Eichhornia speciosa, Kunth. Transverse section of lateral vein of 'lamina' ( $\times 200$ circa). One small normal bundle (n.b.). One larger inverted bundle $(i . b$.$) , higher in leaf, is giving off a branch, also inverted. f_{\bullet}=$ fibres; $p h .=$ phloem; $x y .=x y l e m$. Fig. 26. Pontederia cordata, L. Half transverse section of lamina near apex $(\times 23)$. All bundles inverted $(i . b$.$) or oblique (o.b.) except the median bundle (m.b.) and the three bundles n . b ., n . b^{\prime}$, , and n.b." Fibres $(f$.$) at margin ; h . b .=$ horizontal branch. Fig. 27 . Pontederia cordata, L. The part of the transverse section shown in Fig. 26 which is included between the dotted arrows $(\times 200$ circa $)$. One normal bundle (n.b.) and two inverted bundles (i.b.), one with an inverted branch. m... $=$ cells containing a secretion, probably myriophyllin. Fig. 28. Pontederia cordata, L. Transverse section of petiole near its upper end, outlines of lacunae dotted $(\times 23)$. Fig. 29. Heteranthera reniformis, Ruiz and Pav. Part of transverse section of lamina, including midrib $\left(m . b_{0}\right)(\times 23)$. All the bundles shown are inverted, except the midrib and main lateral. $s .=$ bundle sheath. Fig. 30 . Heteranthera zosteraefolia, Mart. Transverse section of part of ribbon leaf ( $\times 200$ circa $)$, to show one normal and one inverted bundle. 
which the transition from petiole to 'lamina' takes place quite graduallybut also near the margin. Here there is only a single series of vascular strands, among which inversely orientated bundles are very numerous. Some of the lateral veins in the 'lamina' consist of a single, normally orientated bundle, while others consist of a pair of bundles, one normal and one inverted (Fig. 25, p. 490).

Among the Pontederiaceae, we not only find leaves, such as those just described, in which there is a differentiation between petiole and 'lamina', but others, which are ribbon-like, with no distinction of blade and stalk. For comparison with the more highly differentiated types, sections were cut of the ribbon-leaf of Heteranthera zosteraefolia, Mart. Here the midrib and main laterals proved to be normal, but the others-i.e. the majority of the laterals-were inverted. Fig. 30, p. 490, shows two adjacent bundles orientated in opposite ways. The structure of this ribbon-leaf is closely similar to that of the 'lamina' in H. reniformis.

It may be worth noting that a peculiar submerged member of this Family, Hydrothrix Gardneri, Hook. f., described by Goebel, ${ }^{1}$ has, on its long shoots, leaves with a sheathing base and hair-like upper region, whose external morphology distinctly suggests a phyllodic origin. Anatomical evidence cannot be looked for here, since the extremely slender leaves are said to be traversed by a single bundle only.

The presence of inverted bundles in four species of Pontederiaceae representing three genera-in fact, in all the species of which material has been available to the present writer-is a remarkable anomaly which calls for some explanation. It is difficult to see how such a structural peculiarity can be explained as an adaptation, since it is common to leaves otherwise differing notably in type and mode of life. It is equally conspicuous in the very delicate ribbon-leaf of Heteranthera zosteraefolia and in the welldefined, thick 'lamina' of Eichhornia speciosa ; it occurs both in Heteranthera reniformis, in which palisade parenchyma is confined to the upper side, and in Pontederia cordata, in which this tissue is developed towards both surfaces. In the present writer's opinion, this anatomical anomaly is best interpreted on the view that the 'laminae' of the Pontederiaceae, instead of being homologous with the laminae of Dicotyledons, are merely the expanded apices of pre-existing phyllodes: the inverted bundles are thus an indication of the petiolar nature of the organ, and are regarded as an ancestral feature rather than as an adaptation.

But even if the probability of the truth of the phyllode interpretation be admitted for the 'lamina' of the Pontederiaceae, botanists may prefer to regard this group as possessing a unique leaf structure from which no conclusions can be drawn regarding other Monocotyledons. The Pontederiaceae are not, however, the only Family in which we meet with

1 Goebel, K. (19I3).

$\mathrm{K} \mathrm{k}$ 
phyllodic anatomy of the 'lamina'. The present writer has found in the arrow-head blade of Sagittaria montevidensis, Cham. and Schlecht. (Fig. II, p. 479, and Fig. 32), that, besides the normal main bundles (n.b. I) and a series of smaller bundles running near the lower surface $(n . b .2)$, there is a third series of small inverted bundles near the upper surface $(i: b$.$) .$

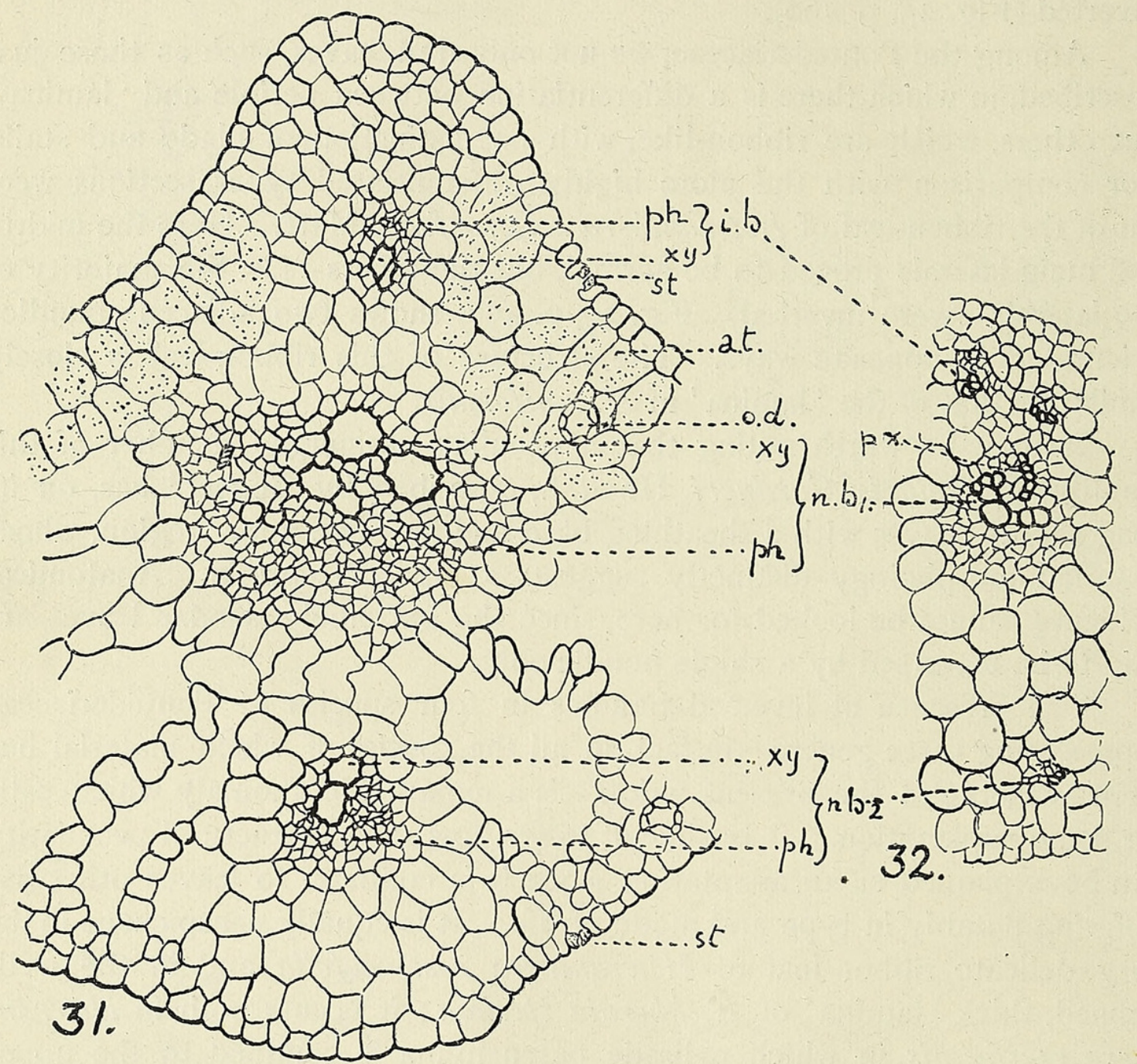

FIGS. 3 I and 32. Sagittaria. ( $n . b .1$ = bundle of main normal series; $n . b .2=$ bundle belonging to second normal series $; i . b .=$ inverted bundle $; x y .=x y l e m ; p h .=$ phloem $;$ a.t. $=$ assimilating tissue $;$ st. $=$ stoma $; 0 . d_{.}=$oil duct). Fig. 3 I. Sagittaria sagittifolia, L. Transverse section of lateral vein of lamina, next but one to midrib ( $x 400$ circa). Fig. 32. Sasittaria montevidensis, Cham. and Schlecht. Small part of transverse section of leaf near margin in region between arrows in Fig. I I, p. 479 ( $\times$ I00 circa). The lower of the two bundles belonging to the normal series $(n . b .2)$ is irregularly placed. Fig. 32 shows that in this genus the inverted bundles are not confined to the ribs.

In Sagittaria sagittifolia, L., inverted strands are a less striking feature, but the lateral ribs, one of which is represented in Fig. 31, show both normal and inverted bundles.

The present writer has not yet succeeded in finding inverted bundles in the blades of any other Family, except the Hydrocharitaceae, in which their existence was already known. In this Family such bundles occur not only in the undifferentiated leaves of Enalus ${ }^{1}$ and Stratiotes, ${ }^{2}$ but also in 
the aerial and floating 'laminae' of Hydrocharis, Limnobium, and Hydromystria. ${ }^{1}$ Solereder, to whose work on this Family we have already referred, regards the Hydrocharitaceae as unique in this respect, but the present writer has, as has just been shown, found comparable cases in the Pontederiaceae and Alismataceae. As we have already pointed out, Solereder recognizes that the anatomy of the lamina in the Hydrocharitaceae is petiole-like-he says: 'Es ist eben einfach Blattstiel- oder Blattscheidenstruktur' - but he leaves this peculiarity as an unexplained parallelism and draws no conclusion therefrom.

The present writer recognizes that, in spite of the anatomical evidence here adduced, Henslow's corollary to de Candolle's theory rests on a slenderer basis of evidence than the main theory itself. It is apparently open to us at present to hold one of several alternative views. De Candolle's theory may be accepted, while Henslow's corollary is entirely rejected, or Henslow's view may be accepted as far as the Pontederiaceae are concerned, with the reservation that the 'laminae', occurring elsewhere among the Monocotyledons, may, in some or all cases, have had a different origin. Or, finally, the view may be taken that the Monocotyledons are all descended from a stock in which the lamina had been entirely lost and that the existing Monocotyledonous blades, whether showing inverted bundles or not, are all 'pseudo-laminae' of later development. This is the view held by the present writer, but she realizes that a complete proof is still lacking and that the theory must at present be treated as provisional only.

\section{Certain obscure anatomical features of Monocotyledonous leaves and their interpretation on the phyllode theory.}

(i) Strands of fibres.

In some Monocotyledonous leaves, besides the vascular bundles, longitudinal strands occur consisting exclusively of fibres. Potamogeton zosterifolius, Schum., furnishes a striking instance of this. One of the figures given by Raunkiær ${ }^{2}$ of the leaf of the winter bud of this species shows, in transverse section, a midrib and four lateral vascular bundles situated about half-way between the upper and lower surfaces of the leaf, while, in addition to a thick strand of fibres close to each margin, there is a series of twentyfive fibrous strands near the upper surface and a second series of sixteen fibrous strands near the lower surface. It seems conceivable that these fibrous strands are derived from ancestral vascular bundles, which have lost their conducting tissue and become reduced to fibres alone. The development of fibres in association with the vascular bundles of the leaves of Monocotyledons often occurs on a most remarkable scale; the xylem and phloem in the leaf-bundles of Agave densiflora (Fig. I 3, p. 479), for instance,

${ }^{1}$ Solereder, H. (1913). $\quad{ }^{2}$ Raunkiær, C. (1896), p. 88, Fig. 49. See also p. 62, Fig. ${ }_{27} 7$ B.

$\mathrm{K} \mathrm{k} 2$ 
are quite inconspicuous in comparison with the associated fibres. In the cortical bundles of the axis in the Potamogetons, transitions can be traced between the rudimentary vascular bundles enclosed in fibrous sheaths and mere bast bundles. ${ }^{1}$ If the fibrous strands of the leaf of Potamogeton zosterifolius are really reduced bundles, it is possible that the leaf originally corresponded in anatomy to such a leaf as that of Narcissus pseudo-narcissus (Fig. I4, p. 479). If that be the case, the fibrous strands may be regarded as a masked and vestigial indication of phyllodic structure. This suggestion is, however, highly tentative, especially as there appears to be no means, in the case of strands of fibres, for determining the orientation of the pre-existing vascular bundle. Whether this suggestion can be extended to other plants must, at present, remain doubtful ; it is probable that fibrous strands may have different origins in different cases.

\section{(ii) Apical openings. ${ }^{2}$}

Openings in the epidermis and subjacent tissues at the apex of the leaf, by means of which the tracheides, in some cases, come to be actually exposed, occur in many submerged plants. In the case of Dicotyledons, these apertures generally arise through the decay and disintegration of water stomates or the disarticulation of an apical trichome. But in the case of a number of Monocotyledons, the pores arise merely by the general destruction of the apical tissues involved, without the loss of any definite organ. The present writer wishes to suggest that the tendency to the formation of these openings may, in the case of Monocotyledons, be associated with the ancestral loss of the lamina and the consequent ' unfinished' condition-if we may so express it--of the apical region of the leaf. The tendency of the veins in phyllodes to converge towards the tip might, not improbably, lead automatically to the formation of an apical complex of tracheides, such as we often find associated with a terminal opening. These apical pores are generally regarded as adaptations for maintaining the current through the plant by forming a passage for the elimination of water. No doubt, in some instances they perform this function, but there are other cases, e.g. Hydrocleis nymphoides, Buchen., in which, though the apical cavity exists, it remains permanently roofed in with cuticle. ${ }^{3}$ It is obvious that this arrangement cannot be explained as an adaptation for the emission of water, but it is possible that it indicates an inherent state of the leaf, which, in other plants, has come to subserve a physiological function.

1 Raunkiær, C. (1903).

2 See Sauvageau, C. (I89I), Weinrowsky, P. (1899), Minden, M. von (I 899), \&c.

3 Sauvageau, C. (1893). 


\section{The significance of the systematic distribution of phyllodic leaf anatomy among the Monocotyledons. ${ }^{1}$}

The two Monocotyledonous Cohorts, in which phyllodic leaf anatomy is at present most widely known, are the Helobiae and the Liliiflorae. In the Helobiae phyllode structure has been found in five Families out of seven, while in the Liliiflorae it has been recorded in six Families out of eight. It is a striking fact that-if the theory be accepted that the Monocotyledons are descended from the Ranalean plexus ${ }^{2}-$ it is these two Cohorts which will probably be regarded as including the members of the Class which have retained the greatest number of primitive features. Within the Liliiflorae we find phyllodic characters conspicuously developed in the central group-the Liliaceae. Within the Liliaceae the most striking feature in the distribution of phyllodic structure is that examples are known from no less than six tribes of the Asphodeloideae. This gains significance from the fact that the type of seedling structure occurring in Anemarrhena, a member of the Asphodeleae, has been regarded by Miss Sargant ${ }^{3}$ as probably 'primitive among Monocotyledons in general as well as among the Liliaceae proper'.

The Juncaceae, Amaryllidaceae, Haemodoraceae, and Iridaceae show every indication of being Families derived from the Liliaceous stock. They have, in many cases, retained the phyllodic anatomy which the present writer regards as a primitive character among the Liliaceae. In the Iridaceae it is perhaps more conspicuously developed than in any other Family, and this fact may possibly be taken to indicate that the Iridaceae arose from the Liliaceous stock at a period when that stock exhibited the phyllodic character even more markedly than it does at the present day. At the risk of seeming far fetched, it may be suggested that the behaviour of the Iridaceae in this respect is comparable with the fact that the American descendants of the Pilgrim Fathers, who left this country in the seventeenth century, have retained a few archaic forms of speech characteristic of the England of that period.

Among the Spathiflorae, phyllodic anatomy is, at present, known only in the genus Acorus of the Araceae (and probably in the related genus Gymnostachys). It would be unsafe to lay much stress upon this individual case, but it is interesting to note that in Acorus the flower is hermaphrodite with free perianth members and with the five trimerous whorls characteristic of typical Monocotyledons. The Pothoideae, to which it belongs, are regarded by Engler ${ }^{4}$ as representing the oldest Family of the Cohort. It may also be recalled that Miss Sargant ${ }^{3}$ considered that the Araceae could be related by seedling characters to the Liliaceae.

1 In connexion with this section see the list of cases, pp. 478-8I.

2 See Sargant, E. (I903), \&c., and Arber, E. A. N., and Parkin (I907).

3 Sargant, E. (1908).

4 Engler, A. (I889). 
The position of the Farinosae is somewhat doubtful, but the Family Pontederiaceae-in which, as we have shown (pp. 488-9I), phyllodic characters are conspicuous in the leaf anatomy-exhibits considerable resemblance to the Liliiflorae. At present no other instances of phyllodic anatomy are known with certainty from the Farinosae. It is, however, not unlikely that the awl-like leaves of certain of the Restiaceae-unless their anatomy is too reduced-might reveal this type of structure on examination, and it is also probable that the vertical leaves of Anarthria ${ }^{1}$ belonging to the same Family, and those of the Xyridaceae and Philydraceae, would prove to conform to the Iris type. The writer hopes in the future to test these suppositions.

Phyllodic leaves of the isobilateral equitant type occur, though rarely, in the Orchidaceae (Microspermae).

At present there appears to be no record of the type of structure here called phyllodic, from any other Cohort of Monocotyledons, but, until the Class has been exhaustively examined from this point of view, it is obvious that this result cannot be accepted as final. It may be useful, however, to take stock of the present position, while recognizing the inevitable incompleteness of the data.

The Cohorts in which phyllodic anatomy is at present unknown are the Pandanales, Glumiflorae, Principes, Synanthae, Scitamineae, and Triuridales. On the theory that the Monocotyledons are descended from Ranalean ancestors, these Cohorts all seem to represent groups which have, on the whole, departed widely in vegetative characters from the original Monocotyledonous stock.

We are thus led to the general conclusion that, so far as our present knowledge goes, phyllodic leaf anatomy is most common in those Cohorts of the Monocotyledons which, in other respects, seem to retain primitive characters. This conclusion appears to the present writer to afford some slight indirect support to the phyllode theory. If the ancestral Monocotyledon possessed a phyllode which performed the same functions as those of a Dicotyledonous blade, it is conceivable that the leaves of its more advanced and modified descendants might eventually lose those vestigial, anatomical characters which originally branded them as petiolar, and that they might ultimately approximate by homoplastic convergence to the structure of a Dicotyledonous leaf. There is also a second phyletic course which may in some cases have led to the loss of phyllodic characters. This is the occurrence of a further degree of reduction in the leaf, involving the disappearance of the petiolar portion and the retention of the leaf-base alone ; in the latter region inverted bundles are characteristically absent. 


\section{SUMMARY.}

\section{External Morphology.}

The first part of the present paper opens with a discussion and amplification of de Candolle's theory of the Monocotyledonous leaf and of Henslow's corollary to that theory. According to de Candolle's theory, the typical Monocotyledonous leaf is interpreted as equivalent to the leaf-base and petiole alone of a Dicotyledon, but the present writer regards certain Monocotyledonous leaves as having been still further reduced until they are equivalent to leaf-bases only. Henslow's corollary explains the 'lamina' of those Monocotyledonous leaves, which show a distinction between petiole and blade, as being merely an expansion of the apical region of the original phyllode and thus not homologous with the lamina of Dicotyledon; the present writer proposes to call such a blade a 'pseudo-lamina' (p. 470). It is pointed out that these theories explain the venation of Monocotyledonous leaves (p. 467).

It is shown that the phyllode theory is in no way inconsistent with Miss Sargant's hypothesis of the geophytic nature of the original Monocotyledonous stock. As regards the embryo, the present writer proposes the further corollary that the single cotyledon of the Monocotyledon is equivalent only to the fused bases and petioles of the Dicotyledonous seed-leaves, the cotyledonary laminae being unrepresented (p. 468).

Asa Gray's tentative suggestion that some Gymnosperm leaves might be equivalent to petioles is recalled and expanded, and the writer suggests its special application to the case of the Gnetales. It is pointed out that on the phyllode theory the Coniferae would be regarded as microphyllous by reduction (p. 472).

\section{Anatomy.}

The phyllode theory has hitherto been based entirely on external morphology, but, in the second part of this paper (p. 473), reason is givenon the ground of a comparison of Dicotyledonous scale-leaves, petioles, and phyllodes with the leaves of Monocotyledons-for the view that the occurrence of inverted vascular bundles, towards the adaxial face of a leaf, may be an indication of phyllodic morphology. A list is added of the cases of such structure in Monocotyledons (pp. 478-8I). In most of the cases to which this list relates, the facts of the anatomy were already known, but no one hitherto appears to have regarded the occurrence of these inverted bundles as furnishing-in correlation with the external form-the key to the morphological interpretation of the Monocotyledonous leaf.

The isobilateral equitant leaf of Iris, \&c., is regarded by the present writer, not as exhibiting congenital concrescence of the two halves of the organ, but 
as a special case of phyllodic structure (p. 482). It is shown that this type of leaf is widely distributed among the Monocotyledons, that it can be closely compared with certain Acacia phyllodes, and that transitions can be traced between it and other types of Monocotyledonous phyllode.

It is suggested that certain examples of 'radial' leaf anatomy among Dicotyledons may possibly be explained on lines similar to those indicated for the case of 'phyllodic' Monocotyledons. It is proposed that, in lieu of regarding a centric leaf with peripheral bundles as an adaptation to xerophilous life, it may be more logical to interpret this type of anatomy as an hereditary indication of the phyllodic (or midrib) nature of the leaf; that it happens to be one of the features which may enable the plant possessing it to become a xerophyte, is considered to be merely a secondary result.

Certain tentative and provisional suggestions are made (p. 493) regarding the interpretation, upon the phyllode theory, of the significance of strands consisting exclusively of fibres, and also of the origin of the 'apical openings' occurring in the leaves of some submerged Monocotyledons.

Anatomical evidence is then brought forward in favour of Henslow's corollary to de Candolle's theory (p. 488). It is shown, apparently for the first time, that the 'laminae' of certain Pontederiaceae (Eichhornia, Pontederia, Heteranthera) all agree in the presence of inverted as well as normal bundles. Inverted bundles are also recorded in the lamina of Sagittaria. Attention is drawn to Solereder's discovery of inverted bundles in the 'laminae' of certain Hydrocharitaceae. It is recognized that Henslow's corollary depends upon a more slender basis of evidence than the main theory, but the present writer is disposed to consider that it is well founded and that the blades of Monocotyledonous leaves are all, in reality, 'pseudo-laminae'.

The systematic distribution of phyllodic anatomy among the Monocotyledons is then dealt with (p. 495), and it is shown that, as far as our present knowledge goes, it does not occur with any frequency outside the Helobiae, Liliiflorae, and Farinosae. On the theory of the origin of the Monocotyledons from the Ranalean plexus-which is accepted by the present writer-the Helobiae and Liliiflorae include those members of the Class which have departed least in character from the ancestral stock; the Farinosae are probably not far distant from the Liliiflorae. In the case of the Spathiflorae, the only record relates to Acorus, which is probably the member of the Araceae retaining the most primitive floral characters -but this may be a mere coincidence. The Cohorts which rarely or never display phyllodic anatomy are those which, on other grounds, are regarded as advanced and highly modified. It is concluded that the systematic distribution harmonizes with the view that the type of anatomy here called 'phyllodic' is an ancient character, revealing the petiolar origin of the Monocotyledonous leaf. 


\section{ACKNOWLEDGEMEnTS.}

In connexion with the present study, the writer has pleasure in acknowledging her indebtedness to the Newnham College Fellowship Committee for a grant for laboratory expenses, and to Miss E. R. Saunders, Director of the Balfour Laboratory, for permission to work there. She also wishes to express her thanks to Mr. R. Irwin Lynch, M.A., Curator of the Cambridge Botanic Garden, for supplying examples of the leaves of more than eighty genera, and also for his unfailing kindness in putting his wide knowledge at her disposal. For supplementary material she is indebted to the Director of the Royal Gardens, Kew, and also to Mrs. J. J. Lister, Miss Muriel Wheldale, and Mr. Rudolf Beer. To Mr. L. A. Boodle, of the Jodrell Laboratory, the writer wishes to express her gratitude for some valuable criticism.

BALFOUR LABORATORY, CAMBRIDGe.

\section{Alphabetical List of Memoirs Cited.}

Arber, A. : See Sargant, E., and Arber, A.

Arber, E. A. N., and Parkin, J. (1907) : On the Origin of Angiosperms. Linn. Soc. Journ. Bot., vol. xxxviii, 1907, pp. 29-80, four text-figures.

Areschoug, F. W. C. (1878): Jemförande undersökningar öfver Bladets Anatomi. Lund, I878, $24^{2}$ pages, eleven plates.

Balicka-Iwanowska, G. (1892-3): Contribution à l'étude anatomique et systématique du genre Iris et des genres voisins. Bibl. Universelle, Archives des sciences physiques et naturelles (Genève), Pér. III, tome xxviii, I892, pp. 4I 3-35; t. xxix, I893, pp. I85-200, 225-4I, three plates, fifteen text-figures.

See also Chodat, R., and Balicka-Iwanowska, G.

BARY, A. DE (1884): Comparative Anatomy of the Vegetative Organs of the Phanerogams and Ferns. Translated by F. O. Bower and D. H. Scott. Oxford, I 884 , xvi +659 pages, $24 I$ figures.

Berger, A. (1908) : Liliaceae-Asphodeloideae-Aloineae, in Das Pflanzenreich, herausgegeben von A. Engler, iv. 38, iii. 2. Leipzig, I908, 347 pages, 8 I 7 text-figures.

Bitter, G. (1897): Vergleichend-morphologische Untersuchungen über die Blattformen der Ranunculaceen und Umbelliferen. Flora, vol. Ixxxiii, 1897, pp. 223-303, thirty-one textfigures.

Bower, F. O. (1884): On the Comparative Morphology of the Leaf in the Vascular Cryptogams and Gymnosperms. Phil. Trans. Roy. Soc., London, vol. clxxv, I885 (for 1884), pp. 565-6I5.

(1888): A Course of Practical Instruction in Botany. 2nd edition, London, I888, ix $+473+$ xlvi pages, fourteen text-figures.

Brandis, D. (1907): Remarks on the Structure of Bamboo-Leaves. Trans. Linn. Soc., London, Ser. 2, Bot., vol. vii, 1904-13, pp. 69-92, four plates.

Brebner, G. See Scott, D. H., and Brebner, G.

BrIquet, J. (1897): Examen critique de la théorie phyllodique des feuilles entières chez les Ombellifères terrestres. Bull. de l'Herbier Boissier, tome v, I897, pp. 424-43, seven textfigures. 
Brown, R. (1810): Prodromus Florae Novae Hollandiae, vol. i, I8 Io, viii +590 pages.

Buchenau, F. (1906): Juncaceae, in Das Pflanzenreich, herausgegeben von A. Engler, iv. 36 . Leipzig, 1906, 284 pages, 777 text-figures.

Candolle, A. P. DE (1827) : Organographie végétale, vol. i. Paris, $1827, x x+55^{8}$ pages.

Chodat, R., and Balicka-Iwanowska, G. (1892): La feuille des Iridées. Journ. de Bot., vol. vi, I 892, pp. $220-3^{2}, 253-67$, one plate, thirteen text-figures.

Compton, R. H. (1911) : Xerophily in the Coniferae and Microphylly. New Phyt., vol. x, I9II, pp. $100-5$.

Eichler, A. W. (1861): Zur Entwickelungsgeschichte des Blattes. Marburg, I861, sixty pages, two plates.

Engler, A. (1889): Araceae, in A. Engler und K. Prantl, Die natïrlichen Pflanzenfamilien, Teil ii, Abt. 3, Leipzig, I889, pp. 102-53, twenty-nine text-figures.

Goebel, K. (1891-3) : Pflanzenbiologische Schilderungen. Teil ii, Lief. i, I891 ; Lief, ii, I893. Marburg, iv +386 pages, thirty-one plates, I 2 I text-figures.

(1905) : Organography of Plants, translated by I. Bayley Balfour. Part II, Oxford, 1905 , xxiv +707 pages, $4 \mathrm{I} 7$ text-figures.

(1913): Morphologische und biologische Bemerkungen. 22. Hydrothrix Gardneri. Flora, N.F., Bd. v (Ganze Reihe, Bd. cv), I913, pp. 88-100, nine text-figures.

Gray, A. (1887): The Botanical Text-book (sixth edition). Part I: Structural Botany, London, I 887 , xii $+44^{2}$ pages, 695 text-figures.

Henslow, G. (1893): A Theoretical Origin of Endogens from Exogens, through Self-Adaptation to an Aquatic Habit. Journ. Linn. Soc. Bot., vol. xxix, I893, pp. 485-528.

(1911): The Origin of Monocotyledons from Dicotyledons, through Self-Adaptation to a Moist or Aquatic Habit. Ann. Bot., vol. xxv, Part II, I9I I, pp. 7I 7-44.

Hill, T. G. (1900): The Structure and Development of Triglochin maritimum, L. Ann. Bot., vol. xiv, I900, pp. 83-107, two plates.

Hochreutiner, G. (1896): Contribution à l'étude des Acacia phyllodinés. Bibliothèque Universelle, Archives des sciences phys. et nat. (Genève), Année IoI, Pér. IV, t. i, No. 3, I 896 , pp. $278-80$.

Lignier, O. (1908-9): Essai sur l'Évolution morphologique du Règne végétal. Bull. de la Soc. Linnéenne de Normandie, Sér. VI, vol. iii, 1908-9, pp. 35-62.

Magnus, P. (1870): Ueber die Anatomie der Meeresphanerogamen. Sitzungs-Ber. d. Gesellsch. naturforsch. Freunde zu Berlin, December 20, I870, pp. 85-90.

Massart, J. (1894) : La récapitulation et l'innovation en embryologie végétale. Bull. de la Soc. Roy. de Bot. de Belgique, t. xxxiii, fasc. I, I894, pp. I 50-247, four plates, fifty-four textfigures.

MINDEN, M. von (1899): Beiträge zur anatomischen und physiologischen Kenntnis wassersecernierender Organe. Bibliotheca Botanica, Bd. ix, Heft 46, I899, seventy-six pages, seven plates.

Parkin, J. : See Arber, E. A. N., and Parkin, J.

PAX, F. (1888): Iridaceae, in Engler, A., and Prantl, K., Die natürlichen Pflanzenfamilien, II. 5, I888, pp. I $37-57$, thirty-five text-figures.

Petit, L. (1887) : Le pétiole des dicotylédones. Mém. de la Soc. des sciences phys. et nat. de Bordeaux, $3^{\text {e }}$ sér., t. iii, I887, pp. $217-404$, seven plates.

- (1889): Nouvelles recherches sur le pétiole des phanérogames. Actes de la Soc. Linnéenne de Bordeaux, t. xliii, I889 ( $5^{\text {e }}$ sér., t. iii), pp. I-6o, four plates.

Prollius, F. (1884): Ueber Bau und Inhalt der Aloïneenblätter, Stämme und Wurzeln. Archiv der Pharmacie, Bd. cxxii, Reihe 3, Jahrg. 63, I884, pp. 553-78, fourteen textfigures.

RAUNKIÆR, C. (1896) : De Danske Blomsterplanters Naturhistorie. Bd. i. Enkimbladede, I, Heliobieae. Kjøbenhavn, I896, I 38 pages, sixty-three text-figures.

(1903): Anatomical Potamogeton-Studies and Potamogelon fluitans. Bot. Tidsskrift, vol. xxv, 1903, pp. 253-80, nine text-iigures.

RE, L. (1894): Anatomia comparata della foglia nelle Amarillidacee. Annuario del R. Ist. Bot. di Roma, Ann. V, I894 (for I 892-4), pp. I55-73, two plates.

Salisbury, E. J. (1916): The Emergence of the Aerial Organs in Woodland Plants. Journ. of Ecology, vol. iv, I916, pp. I 2 I-8, seven text-figures. 
SARGANT, E. (1903): A Theory of the Origin of Monocotyledons, founded on the Structure of their Seedlings. Ann. Bot., vol. xvii, 1903, pp. I-92, seven plates, ten text-figures.

(1904): The Evolution of Monocotyledons. Bot. Gaz., vol. xxxvii, I904, pp. 325-45, six text-figures.

(1908): The Reconstruction of a Race of Primitive Angiosperms. Ann. Bot., vol. xxii, 1908, pp. I I I-86, twenty-one text-figures.

and ARber, A. (1915): The Comparative Morphology of the Embryo and Seedling in the Gramineae. Ann. Bot., vol. xxix, 1915, pp. 16I-222, two plates, thirty-five text-figures.

SAUvageau, C. (1891): Sur les feuilles de quelques monocotylédones aquatiques. Ann. d. sci. nat., Sér. VII, Bot., t. xiii, I89I, pp. I03-296, sixty-four text-figures. (Also published as: Thèses présentées à la faculté des sciences de Paris, Sér. A, No. I 58 , no. d'ordre $720,189 \mathrm{I})$.

- (1893): Sur la feuille des Butomées. Ann. des sci. nat., Sér. VII, Bot., t. xvii, I 893 , pp. 295-326, nine text-figures.

ScharF, W. (1892): Beiträge zur Anatomie der Hypoxideen und einiger verwandter Pflanzelı. Bot. Centralbl., Jahrg. I3, Bd. lii, I892, pp. I45-53, I 77-84, 209-I 7, 24I-9, 289-96, 32I-7, one plate.

SchmidT, C. (1891) : Ueber den Blattban einiger xerophilen Liliifloren. Bot. Centralbl., Jahrg. 12 , Bd. xlvii, I891, pp. I-6, 33-42, 97-107, 164-70, two plates.

Schulze, R. (1893): Beiträge zur vergleichenden Anatomie der Liliaceen, Haemodoraceen, Hypoxidoideen und Velloziaceen. Engler's Bot. Jahrb., Bd. xvii, I893, pp. 295-394, two plates.

Scott, D. H., and Brebner, G. (1893): On the Secondary Tissues in Certain Monocotyledons. Ann. Bot., vol. vii, 1893 , pp. 2 I -62 , three plates.

Solereder, H. (1913): Systematisch-anatomische Untersuchung des Blattes der Hydrocharitaceen, Beihefte zum Bot. Centralbl., Bd. xxx, Abth. I, I913, pp. 24-104, fifty-three text-figures.

Trécul, A. (1853): Mémoire sur la formation des feuilles. Ann. des sci. nat., Sér. III, Bot., t. xx, I853, pp. 235-31 4, six plates.

(1872): Du sucre propre dans les feuilles des Aloès. Ann. des sci. nat., Sér. V, Bot., t. $x i v, 1872$, pp. $80-90$.

(1876): Théorie de la modification des rameaux pour remplir des fonctions diverses, déduite de la constitution des Amaryllidées, etc.. Comptes rendus de l'Acad. des Sciences, t. lxxxiii, I876, pp. ${ }^{258-63}$.

Weinrowsky, P. (1899): Untersuchungen über die Scheitelöffnung bei Wasserpflanzen. Fünfstück's Beiträge zur wiss. Bot., Bd. iii, I 899 , pp. 205-47, ten text-figures. 
Annals of Botany,

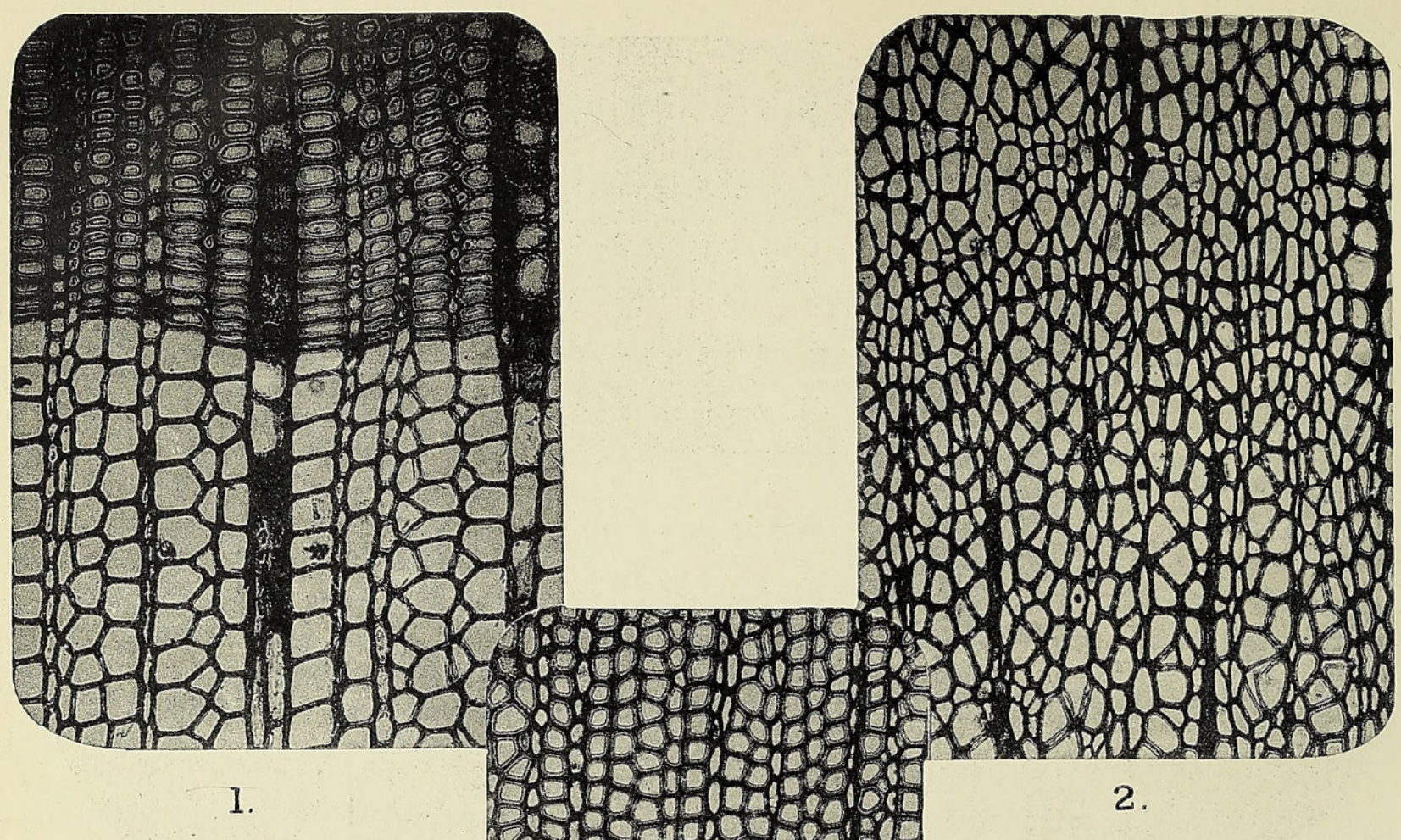

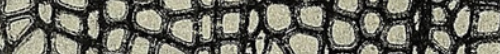

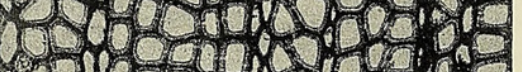

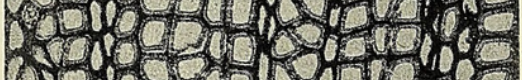

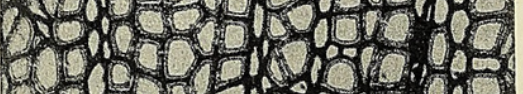

1.4. H

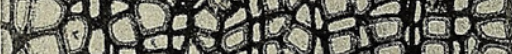

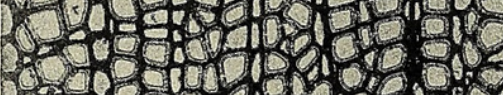

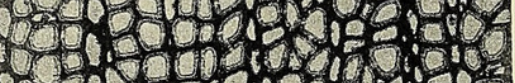

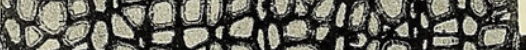

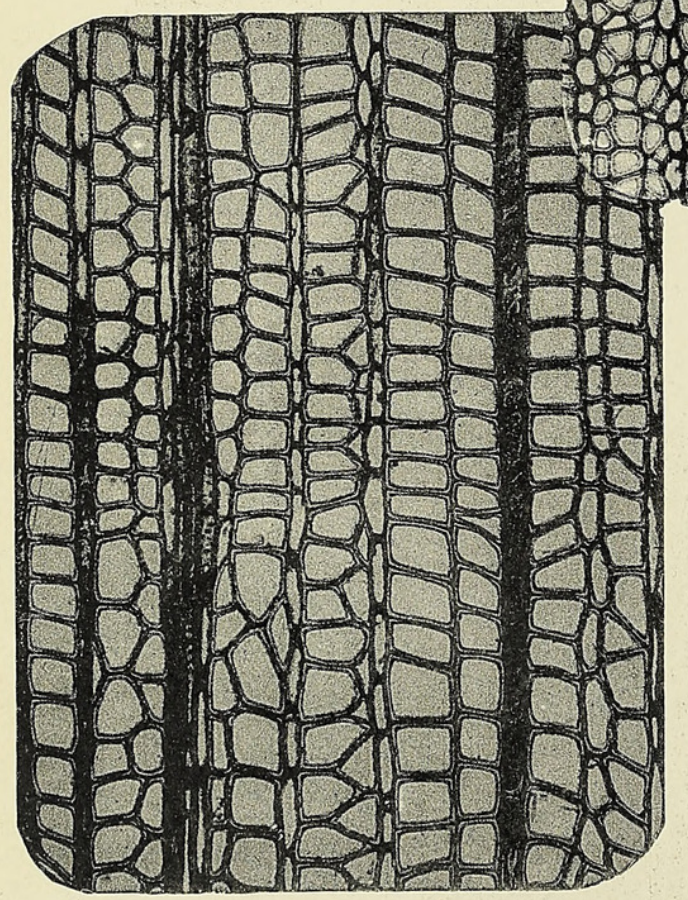

4
3.

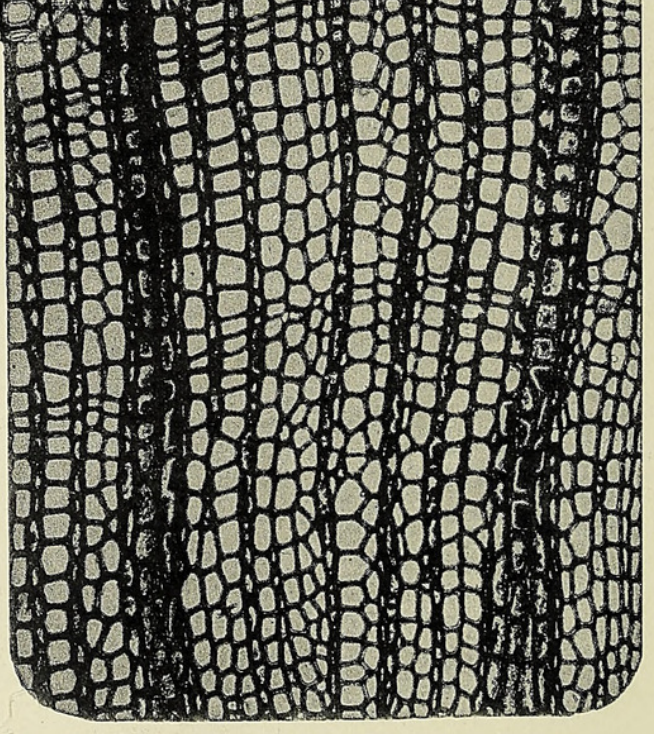

5.

BAILEY \& THOMPSON - TROCHODENDRON, TETRACENTRON \& DRIMYS. 


\section{$2 \mathrm{BHL}$ Biodiversity Heritage Library}

Arber, Agnes Robertson. 1918. "The phyllode theory of the monocotyledonous leaf, with special reference to anatomical evidence." Annals of botany 32, 465-501. https://doi.org/10.1093/oxfordjournals.aob.a089687.

View This Item Online: https://www.biodiversitylibrary.org/item/238284

DOI: https://doi.org/10.1093/oxfordjournals.aob.a089687

Permalink: https://www.biodiversitylibrary.org/partpdf/320229

\section{Holding Institution}

Smithsonian Libraries

\section{Sponsored by}

Biodiversity Heritage Library

\section{Copyright \& Reuse}

Copyright Status: Not in copyright. The BHL knows of no copyright restrictions on this item.

This document was created from content at the Biodiversity Heritage Library, the world's largest open access digital library for biodiversity literature and archives. Visit BHL at https://www.biodiversitylibrary.org. 